\title{
Megabeds in Istrian Flysch as markers of synsedimentary tectonics within the Dinaric foredeep (Croatia)
}

\author{
Krešimir Petrinjak*, Marko Budić, Stanislav Bergant and Tvrtko Korbar \\ Croatian Geological Survey, Department of Geology, Sachsova 2, 10000 Zagreb, Croatia; (“corresponding author: kpetrinjak@hgi-cgs.hr)
}

doi: $10.4154 / g c .2021 .07$

Article history:

Manuscript received January 15, 2020

Revised manuscript accepted February 18, 2021

Available online May 06, 2021

\begin{abstract}
Istrian Flysch was deposited during the Eocene in the Dinaric foredeep and is composed of hemipelagic marls and various gravity flow deposits. The latter are predominantly $5-40 \mathrm{~cm}$ thick turbidites, developed mostly as laminated and cross-rippled sandstone beds (Tb-e, Tc-e and Td-e Bouma sequences). In addition to the turbidites, there are deposits characterized by a significant thickness, occasionally more than $10 \mathrm{~m}$, described as complex (bipartite) megabeds. The megabeds are composed of debrites in the lower part (Division I), and high-density turbidites in the upper part (Division II). The distinct clast composition of each megabed indicates that the lithoclasts were derived from tectonically active slopes and fault scarps along which collapses of the different parts of the Cretaceous to Palaeogene neritic carbonate succession, that underlie the Flysch, occurred. The Division II deposits are well cemented, normally graded calcirudite/calcarenites composed mostly of orthophragminids, nummulitids, and red algae, originating from outer ramp environments. Redeposited marl, observed in the matrix of the debrites and as intraclasts in some megabeds, implies that the collapses along the synsedimentary fault scarps and steep slopes also occurred within the foredeep itself, during the rapid tectono-sedimentary evolution of the Dinaric foreland basin.
\end{abstract}

Keywords: Adriatic microplate, Dinaric foreland basin, mass transport deposits, Eocene, External Dinarides compressed basinal sediments composed of arenite and marl alternations and c) foraminiferal debris. The turbidite part is normally graded, composed mostly of foraminiferal debris and lacking large lithoclasts (MARJANAC, 1993). In the slightly older counterparts of the Dinaric foreland basin north of Istria, (Friuli and the Julian basin in Italy and Slovenia), the mass transport deposits (MTDs) that are described in 5 subunits (U1-U5) were deposited by different depositional processes. The authors (OGATA et al., 2014) indicate that the processes generating the Friuli and Julian MTDs are composed of a) a debris-blocky flow/avalanche bearing out-sized carbonate and siliciclastic slide blocks (responsible for the deposition of subunits U1 and U2), b) a diluted debris/grain flow (deposition of subunit U3), and c) an upper highto low-density fully turbulent flow (deposition of subunits U4 and U5). Mass flows can transport and incorporate both intra- and extra-basinal material and their formation commonly implies processes of stratal disruption and lithological mixing and thus forming a characteristic "block-in-matrix" fabric (PINI et al. 2012; OGATA et al., 2020). Thus, the single event beds that display bipartite organization, with each part inferred to reflect a distinct depositional process, are referred also as MTDs. Among other MTDs, bipartite megabeds, composed of debrite and turbidite parts, are also described in the Dinaric wedge-top basin in Northern Dalmatia (GOBO et al., 2021).

In this research, sedimentological and petrographic data about megabeds of the Istrian Flysch is used to shed some light on the environmental conditions, depositional mechanisms, and the origin of the resedimented coarse-grained carbonate material. To determine the variations and provenance of the carbonate material, qualitative and quantitative analyses of carbonate clasts were performed. Furthermore, the analysis of bioclastic grains was carried out to determine the original depositional palaeoen-

vironments of the redeposited bioclasts. The relatively tectonically of a) extra basinal clasts - Foraminiferal limestones, b) rolled and 
undisturbed Dinaric foreland deposits that were not involved in the External Dinarides fold-and-thrust belt are exclusively exposed in centra Istria since other equivalent parts of the foreland are covered by Neogene deposits and/or by the Adriatic Sea (KORBAR, 2009). Thus, Istria is an excellent location for further studies of the rather complex foreland basin evolution.

There are no deep seismic and exploration wells in Istria needed for relevant basin modeling. However, the presented research resulted from some insight in the formation, composition and spatial distribution of some megabeds. For further correlation of the studied megabeds, more detailed geological mapping and precise biostratigraphic analyses are needed. So far, this research has provided new data about the Istrian megabeds regarding the composition, and provenance of the carbonate material, facies models and triggering mechanisms.

\section{GEOLOGICAL SETTING}

The Istrian peninsula is located on the northwestern part of the Eastern Adriatic Coast and it predominantly belongs to the Adriatic foreland (Fig 1). The NE mountain belt of the peninsula (Fig. 1) belongs to the fold-and-thrust belt of the External Dinarides, formed during Alpine orogenesis, caused by the collision of the Adriatic microplate (Adria) and the Eurasian plate (SCHMID et al., 2008; KORBAR, 2009; ŠPELIĆ et al., 2021). The oldest rocks on the Istrian peninsula are the Jurassic and Cretaceous limestones that were deposited on the pre-orogenic long-lasting Adriatic carbonate platform (VLAHOVIĆ et al., 2005). A regional unconformity separates the Jurassic-Cretaceous shallow-marine carbonate succession from the Palaeogene synorogenic carbonates deposited in the distal foreland (OTONIČAR, 2007). This Late Cretaceous and Early Palaeogene unconformity is marked by palaeokarst that occurred during the forebulge uplift and the emersion of the Adriatic Carbonate Platform (OTONIČAR, 2007). Also, a broad Istrian anticline, striking NE-SW, was probably formed during the Late Cretaceous, since the deformed and palaeokarstified Cretaceous carbonates are diachronously overlain by the Palaeogene succession (MATIČEC et al., 1996). The lowermost part of the Palaeogene succession is characterized by localized occurrences of the freshwater or brackish Kozina beds (ŠIKIĆ \& POLŠAK, 1973; MARJANAC \& ĆOSOVIĆ, 2000; ĆOSOVIĆ et al., 2008). The Kozina beds are overlain by Ypresian to Middle-Late Lutetian Foraminiferal limestones (DROBNE, 1977; MARJANAC \& ĆOSOVIĆ, 2000) which were deposited on a fully marine carbonate ramp (ĆOSOVIĆ et al., 2004) developed in the distal part of the Dinaric foreland basin (OTONIČAR, 2007).

The Foraminiferal limestones are often informally subdivided into four separate members: Miliolid-, Alveolinid-, Nummulitid- and Discocyclina limestones (DROBNE 1977; ŠIKIĆ \& PLENIČAR, 1975; VELIĆ et al., 2003; VLAHOVIĆ \& VELIĆ, 2009). The units are generally in superposition and indicate progressive deepening of the ramp (ĆOSOVIĆ et al., 2004) during the migration of the foreland basin to the SW (OTONIČAR, 2007; KORBAR, 2009). The Foraminiferal limestones are overlain by

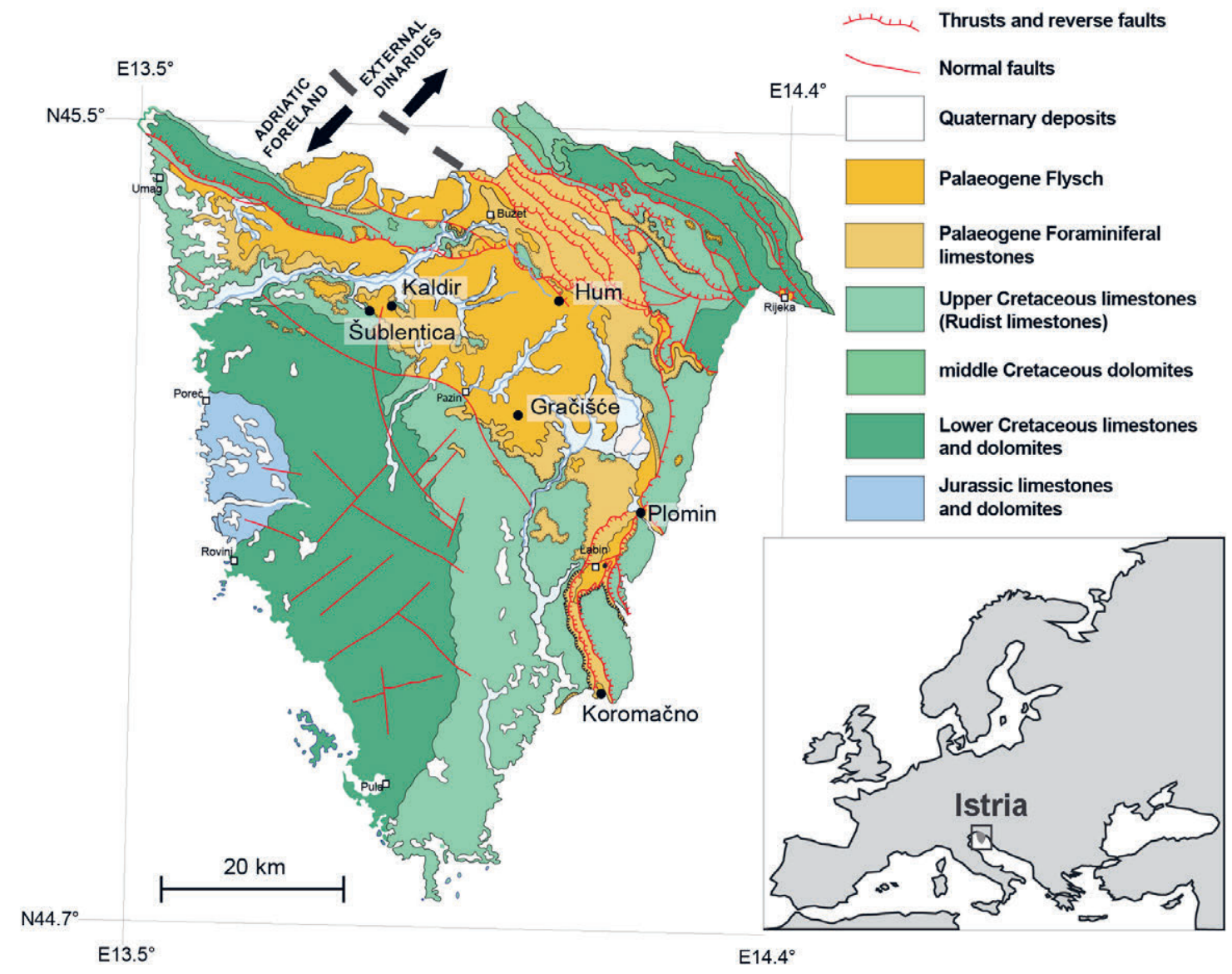

Figure 1. The geological map of the Croatian part of the Istrian peninsula with the studied locations indicated by black circles (CROATIAN GEOLOGICAL SURVEY, 2009). Globigerina marls are not separated as a lithostratigraphic unit but as a member within the Foraminiferal limestones. However, according to new data and more detailed maps, Globigerina marls within the investigated area, are reclassified and published as a member within the Istrian flysch (BERGANT et al., 2020) as presented in Fig. 2. 
the so-called Transitional beds composed of "Marls with crabs" and "Globigerina marls". The "Marls with crabs" are clayey fossiliferous wackestones and packstones (ŠIKIĆ \& PLENIČAR, 1975; MARJANAC \& ĆOSOVIĆ, 2000; TARLAO et al., 2005), deposited during the gradual transition from the neritic carbonate ramp to the deeper-water distal foredeep. Massive "Globigerina marls" (or "Subbotina Marls") are deposited in deeper environments and are considered to be hemipelagic deposits (JURAČIĆ, 1980). The clastic part of the foreland succession is deposited in the foredeep and is referred to as Flysch (MARINČIĆ, 1981). In the wider eastern Adriatic region Flysch is recognized as a major lithostratigraphic unit, which marks the beginning of the Dinaric orogenic deformations in the area (AUBOUIN et al., 1970; BABIĆ \& ZUPANIČ, 1983; KORBAR, 2009). The whole Istrian Palaeogene succession (Figs. 1 and 2) is probably deposited within an underfilled peripheral foreland basin as described by SINCLAIR (1997), with Flysch deposited in the foredeep in front of the once migrating Dinaric wedge (OTONIČAR, 2007; KORBAR, 2009).

Based on the plankton and benthic foraminiferal ratio, ŽIVKOVIĆ \& BABIĆ (2003) have estimated the water depth of the foredeep to about $900-1200 \mathrm{~m}$. The Flysch is characterized by the alternation of hemipelagic marls and gravity-flow deposits (predominantly turbidites) composed of a) mixed carbonate-siliciclastic detritus or b) carbonate detritus (MAGDALENIĆ, 1972; MARINČIĆ, 1981; BABIĆ \& ZUPANIČ, 1996; MARINČIĆ et al., 1996; BERGANT et al., 2003). Mixed carbonate-siliciclastic turbidites show longitudinal palaeotransport directions toward the ESE which led to the conclusion that the material was supplied from the rising Dinarides and from the Alps (MAGDALENIĆ, 1972; MARINČIĆ et al., 1996; BABIĆ \& ZUPANIČ, 1996). These turbidites are regarded as turbidites deposited by low density turbidity currents (MARINČIĆ et al., 1996). Carbonate beds are often thin turbidites but also thick, bipartite beds composed of breccias, conglomerates, bioclastic arenites/siltites, and marls (BABIĆ \& ZUPANIĆ, 1996; BERGANT et al., 2003), and show a palaeotransport direction towards the NNE, generally perpendicular to the SE direction of the mixed carbonate-siliciclastic turbidites (BABIĆ \& ZUPANIČ, 1996). BABIĆ \& ZUPANIČ (1996) conclude that the carbonate detritus was supplied from the foreland uplift (forebulge), situated to the south, characterized by carbonate shoals and subaerial exposure.

The progressive evolution of the Istrian foredeep fill has been documented by MARINČIĆ et al. (1996) and is described as the Istrian Flysch - a succession of clastic rocks characterized by a coarsening upward trend and outlined with zones of "distal" and "proximal" Flysch. According to MARINČIĆ et al. (1996), the total thickness of the Flysch succession is estimated to be around 300-350 m (Fig. 2).

Although some published (MIKES et al., 2008) and unpublished studies argued for a Late Oligocene or even Miocene age of the Istrian and Dalmatian Flysch, the majority of the researchers confirm a Middle Eocene age (AUBOUIN et al., 1970; KRAŠENINNIKOV et al., 1968; PICCOLI \& PROTO DECIMA, 1969; MAGAS̆, 1973; POLŠAK \& ŠIKIĆ, 1973; ŠIKIĆ \& POLŠAK, 1973; ŠIKIĆ \& PLENIČAR, 1975; BENIĆ, 1991; ŽIVKOVIĆ \& BABIĆ, 2003; BABIĆ et al., 2007; ŽIVKOVIĆ \& GLUMAC, 2007). We accepted the Middle Eocene age proposed by BABIĆ et al. (2007) and ĆORIĆ et al. (2008), since their data was obtained from the investigated logged successions and by more than one biostratigraphic method.

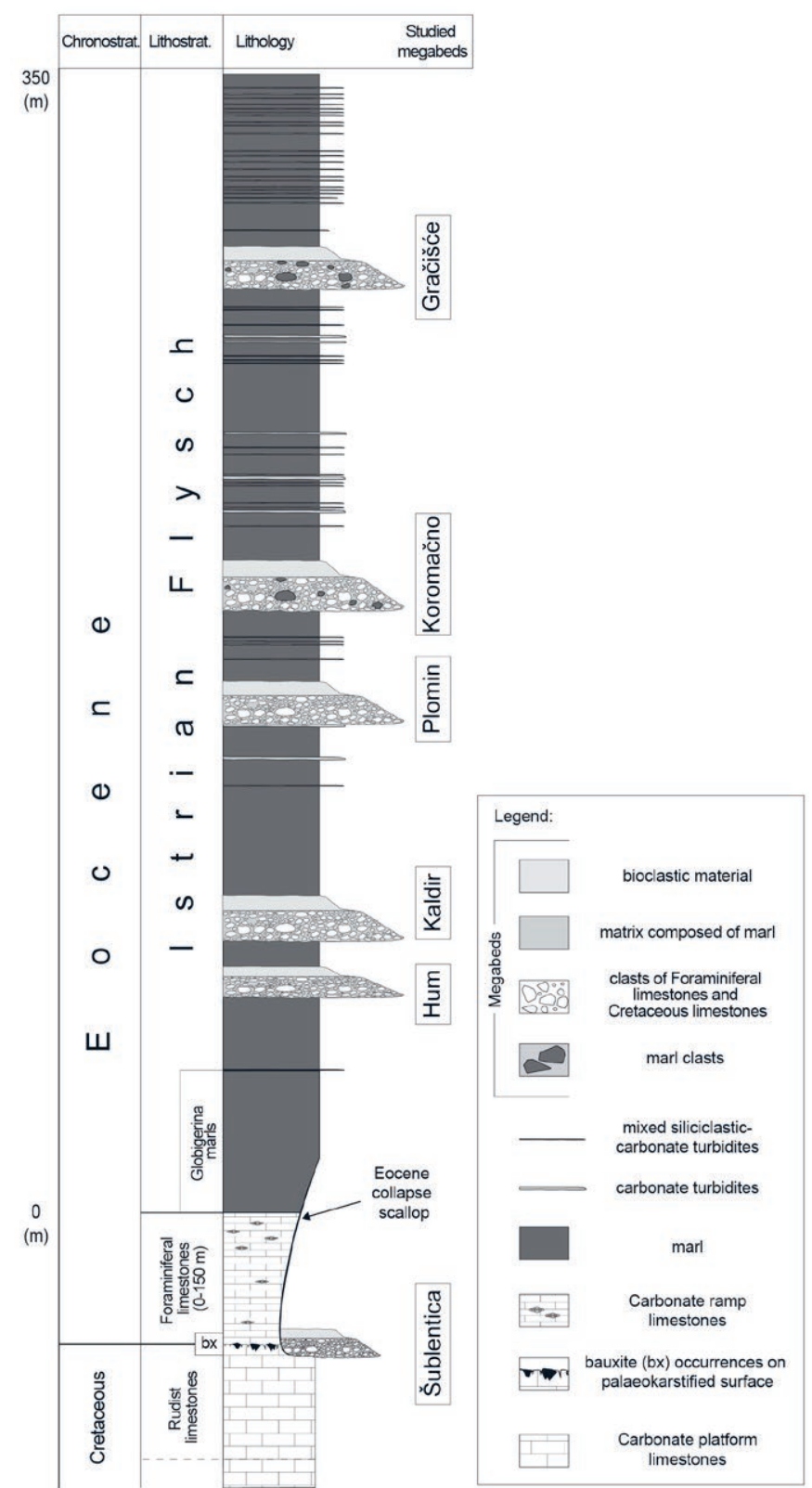

Figure 2. The schematic geological column of the Middle Eocene Istrian Flysch succession and the underlying Cretaceous and Palaeogene neritic carbonates, with the general relative stratigraphic positions of the investigated sections. Intervals of the underlying Cretaceous Rudist limestones and Palaeogene Foraminiferal limestones are not in a general scale given for Flysch.

For this study, six different megabeds were investigated. The locations of the investigated beds are presented in Fig 1. The relative stratigraphic position of each megabed was determined according to the data of direct observation in the field, from the published and unpublished geological maps, and the results of previous biostratigraphic research. We can conclude that the studied megabeds are present in the different stratigraphic positions within the Istrian Flysch succession. The Kaldir, Šublentica, and Hum megabeds are located in the lower part, while the Gračišće, Koromačno, and probably the Plomin megabeds are in the middle part of the Istrian Flysch succession (Fig. 2). According to ŽIVKOVIĆ \& BABIĆ (2003) the age of the Gračišce megabed is Bartonian (plankton foraminifera zone P11-P13). The Kaldir megabed is considered to be of a Middle Eocene age based on the vicinity of the investigated sections by ŽIVKOVIĆ \& GLUMAC (2007). The ages of other megabeds are based on the data pro- 

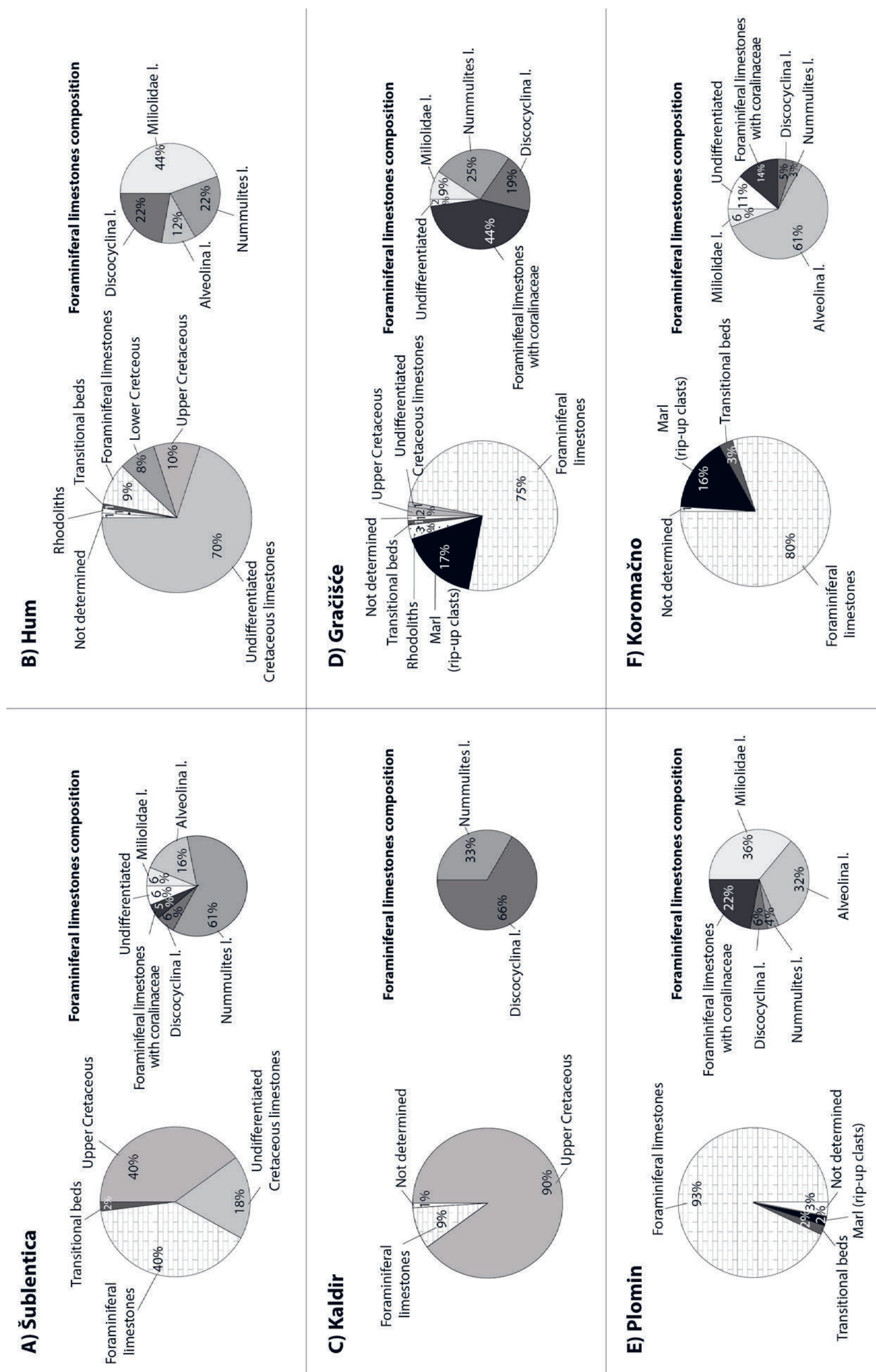
vided on basic geological maps: the Plomin megabed - Middle Eocene according to ŠIKIĆ \& POLŠAK (1973), the Koromačno megabed - Middle to Upper Eocene according to MAGAŠ (1973), the Šublentica megabed - Middle Eocene according to POLŠAK \& ŠIKIĆ (1973), and the Hum megabed - Middle Eocene according to ŠIKIĆ \& PLENIČAR (1975). Since the information on the megabeds age is somewhat scarce, their precise correlation is not yet possible. For a better understanding of the stratigraphic relationships between the megabeds more precise dating is needed.

\section{METHODS}

During the field investigation, information on boundary types, sediment composition, layer thickness, grain size, fossil content, and internal structures was collected and presented on graphic logs. Because of the recognized general compositional variation within all the studied megabeds, two different methodologies were used:

1) Analysis of coarse-clast composition of breccia, referred to as Division I;

2) Analysis of the composition of calcirudites and calcarenites, referred to as Division II.

1) To determine the clast compositions representative for Division I of each megabed, the most exposed parts of the outcrops were selected. Between 200 and 300 clasts within the selected areas were classified and counted. The clasts were categorized based on their fossil content and lithological characteristics. The fossil content was determined by hand lens examination in-situ where possible. In addition, some samples were analyzed microscopically. The categories are based on the lithostratigraphic units presented on the Geological map (Fig. 1). The categories are: Lower-, Upper-, or undifferentiated Cretaceous limestones, Foraminiferal limestones, Flysch (Marls), rhodoliths, and undetermined clasts. The large rhodoliths ( $>5 \mathrm{~cm}$ in diameter), observed in two megabeds are added to separate categories although they are not attributed to any lithostratigraphic unit presented in Fig 1. The Cretaceous clasts were classified on the basis of their foraminiferal content according to VELIĆ (2007). Foraminiferal limestones were additionally separated according to their predominant large benthic foraminifera content of the Miliolid-, Alveolinid-, Nummulitid- or Discocyclina limestones as described by POLŠAK \& ŠIKIĆ, (1973); ŠIKIĆ \& POLŠAK, (1973); ك̌IKIĆ \& PLENIČAR, (1975); VLAHOVIĆ \& VELIĆ, (2009), and an additional Algal foraminiferal limestones category. Clasts of Foraminiferal limestones abundant in red algae (rhodoliths and coralline debris) were separated out as Algal foraminiferal limestones. The Foraminiferal limestones with abundant glauconite grains were categorized as Transitional beds. Clasts that had no distinguishable features were labeled as "not determined". Photomicrographs of the most characteristic clasts for each bed are presented as a supplement (Plates 1, 2, and 3). Limestone clasts were distinguished according to DUNHAM's (1962) classification modified by EMBRY \& KLOVAN (1971).

Table 1. Results of Division II bioclastic material analysis.

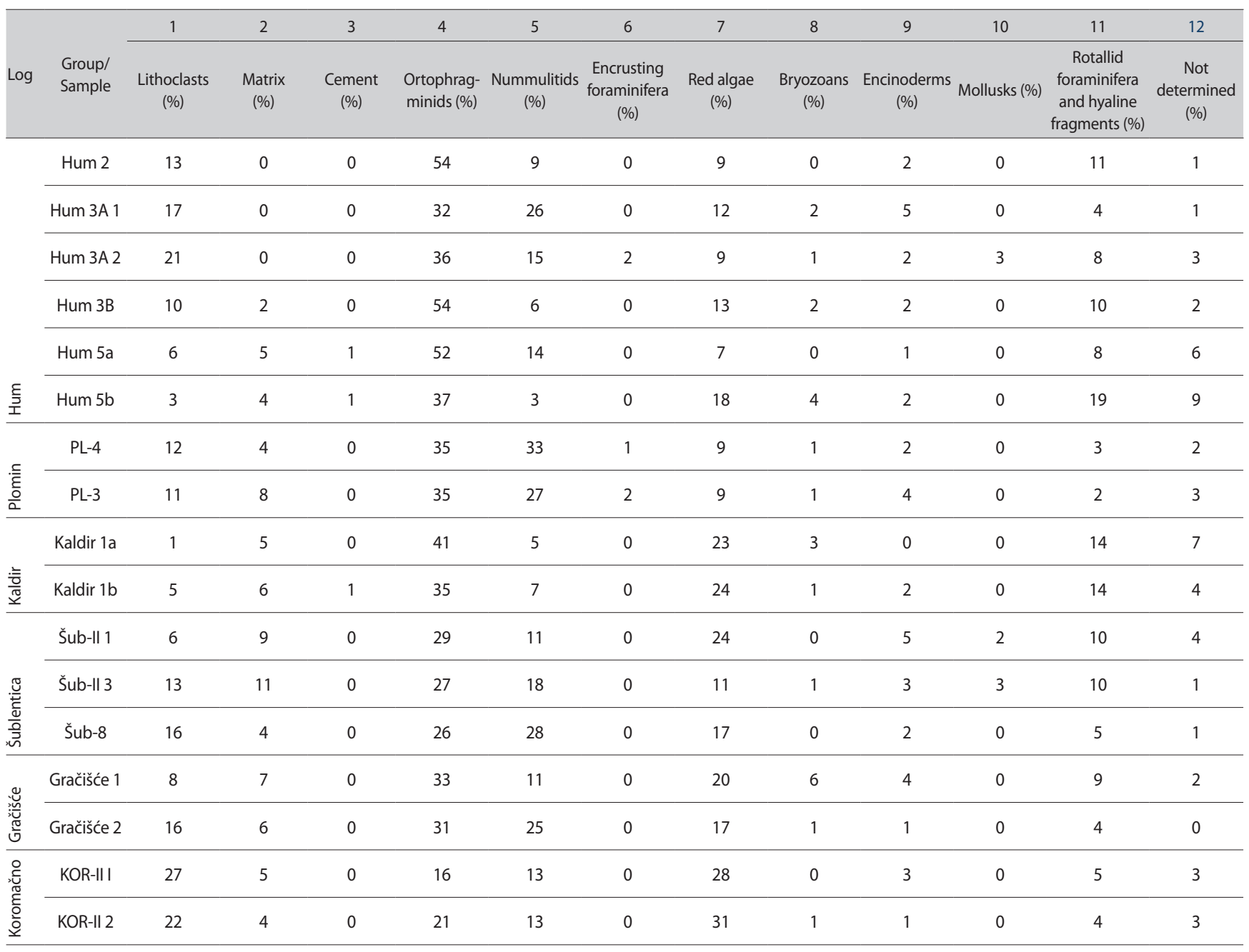




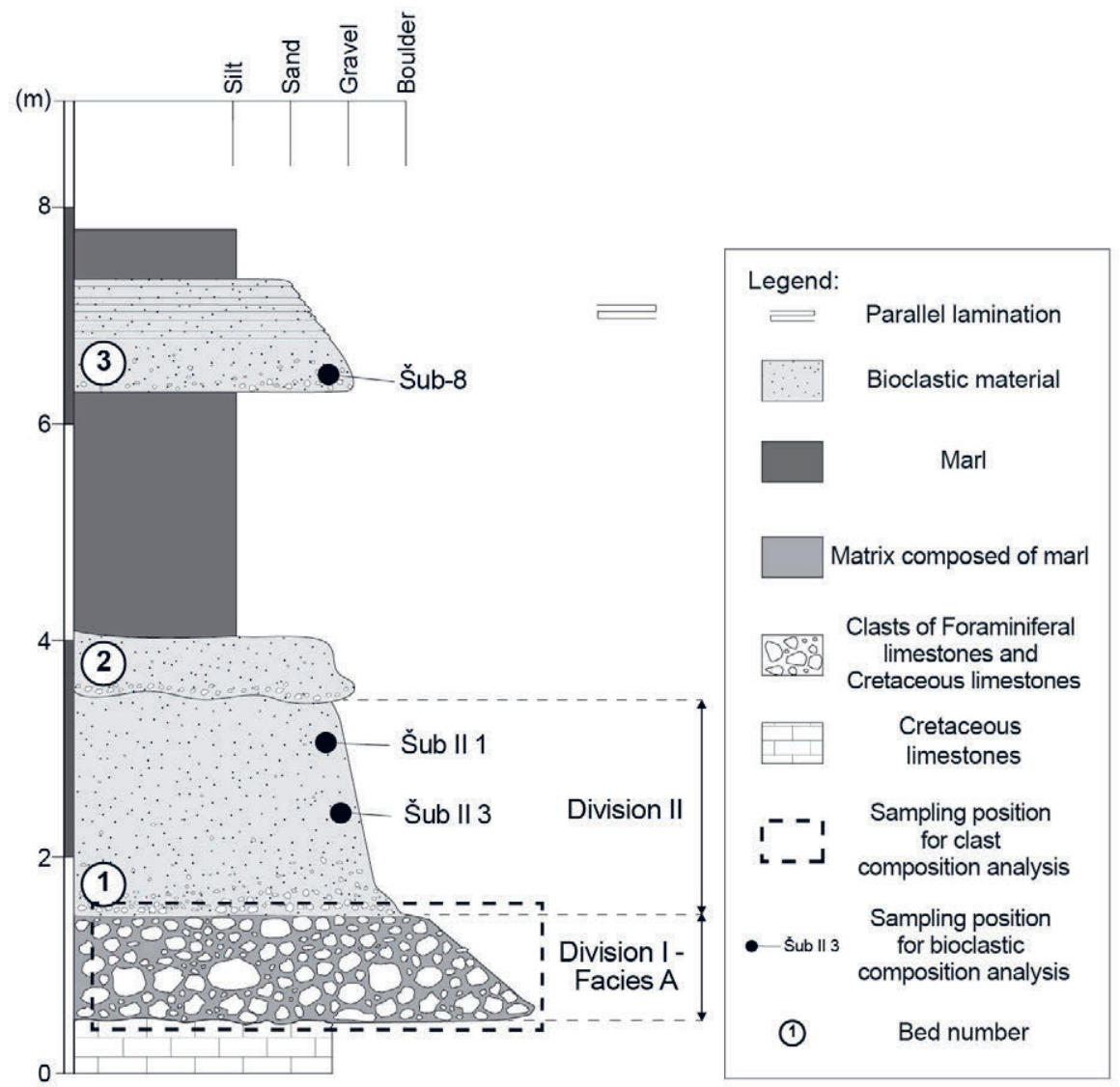

Figure 4. The Šublentica column shows an unconformable (erosional) contact of the Cretaceous limestones and the overlying Šublentica megabed (Istrian Flysch).

2) To determine the composition of calcirudites and calcarenites, thin sections of 17 selected samples were prepared and analyzed by standard petrological microscope. The sampling locations are marked on each log. The Division II samples were determined as bioclastic calcarenites to calcirudites composed predominantly of skeletal debris. The modal distribution of the components in thin section was estimated using a point-counting method described in FLÜGEL (2004). During point-counting, the constituents were classified into 12 groups: 1) lithoclasts, 2) matrix - micrite, 3) cement - sparite, 4) orthophragminid, 5) nummulitid, 6) encrusting foraminifera, 7) red algae, 8) bryozoans, 9) echinoderms, 10) molluscs, 11) hyaline fragments and 12) non-determinable grains. The modal distribution of the main constituents was estimated by point-counting 200-300 grains.

Due to sparse directional structures in the Istrian megabeds, the palaeotransport directions have been measured only in one location (Hum). The structures used to measure palaeotransport directions are ripple marks and a flute cast.

\section{RESULTS}

All the six studied megabeds are distinguished from other gravity flow deposits of Flysch succession by their thickness, composition, and internal bipartite structure. Clast composition for all Division I breccia is given in Fig 3., while the composition of the analyzed Division 2 calcirudite and calcarenite is given for each studied megabed in Table 1.

Within Division 1, two facies types are distinguished, as Facies A and Facies B. Facies A is a clast supported breccia with sparse marl matrix. Facies B is a chaotic, marl dominated, matrixrich breccia with rip-up clasts, and a greater total thickness than Facies A.

\subsection{The Šublentica Section}

The unconformable contact of the Istrian Flysch and the Cretaceous limestones is described at the Šublentica section (WGS84 coordinates: lat $45^{\circ} 19^{\prime} 2.3808^{\prime \prime}$, long $13^{\circ} 48^{\prime} 29.8404^{\prime \prime}$ ). A hiatus was recognized in this section and the megabed directly overlies the Upper Cretaceous Rudist limestones (Fig. 4). The boundary is discordant and erosional (Fig. 5) suggesting tectonic tilting and the partial collapse of the underlying neritic carbonates prior to or synchronously with the deposition of the megabed. The Division I breccia interval is $1.5 \mathrm{~m}$ thick, poorly sorted and clast supported. Carbonate clasts are from 0.1 to $1 \mathrm{~m}$ in size. Upper Cretaceous limestones $(40 \%)$ and Foraminiferal limestones clasts $(40 \%)$ predominate, while undifferentiated Cretaceous limestone clasts (18\%) and Transitional beds (limestones with glauconite; $2 \%$ ) are less abundant. The matrix is composed of marl and large benthic foraminifera (nummulites and orthophragminids). Fig. 3a shows the composition of the Division I breccia, with selected clast microfacies photomicrographs of Foraminiferal and Cretaceous limestones presented in Plate $1 \mathrm{~A}, \mathrm{~B}$, and C. The breccia gradually transitions to the Division II interval which consists of normally graded calcirudite and up-section to normally graded calcarenites. The most common constituents of Division II material are orthophragminids (26-29\%), nummulitids (11-28\%), red algae (11-24\%), and lithoclasts (6-16\%). The proportions of all constituents in the investigated samples are shown in Table 1 and illustrated in Plate 1D. The section ends with the alternation of marl and amalgamated normally graded calcirudite beds (Fig. 4).

\subsection{The Hum Section}

A $40 \mathrm{~m}$ thick interval of the Palaeogene foredeep basin fill was logged near the town of Hum (WGS84 coordinates: lat 45 $21^{\prime}$ 


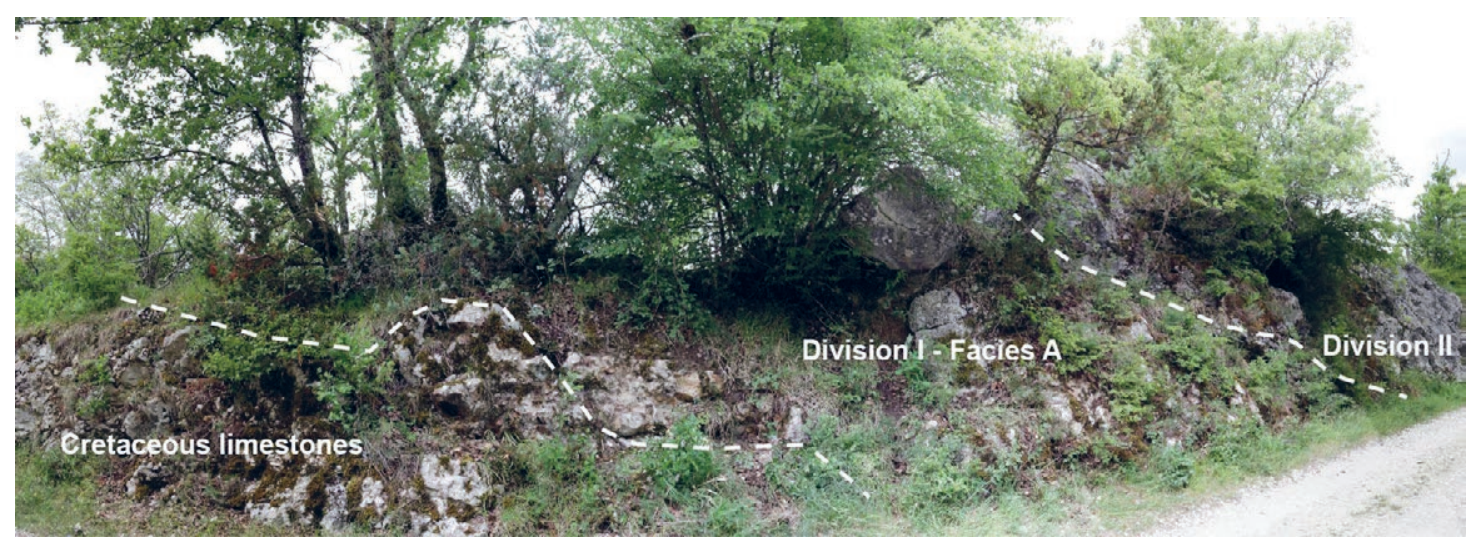

Figure 5. Photograph of the Šublentica outcrop showing a discordant and erosional boundary between the Cretaceous limestones and overlaying megabed.

3.5706", long $14^{\circ} 2^{\prime}$ 42.5466", Fig. 6). The interval is composed of an alternation of marl and five carbonate beds. The most prominent bed is the $9 \mathrm{~m}$ thick megabed Hum 3 (Fig. 7A) which shows the characteristic bipartite structure with visible Division I and Division II components. The other carbonate turbidite beds (labeled Hum 1, 2, 4, 5 on Fig.6) are composed of normally graded bioclastic calcirudite/calcarenite of various thicknesses $(0.6-3 \mathrm{~m})$. The lower bedding surface of each bed is sharp and erosional, implying that the gravity flow eroded previously deposited basinal sediments. The Hum 3 megabed is composed of Division I breccia/conglomerate in the lower/bottom part, and the Division II - normally graded calcirudite/calcarenite in the upper part. The maximum thickness of the laterally thinning breccia/conglomerate interval is $5 \mathrm{~m}$, and the lower bedding surface is erosional. The majority of visible clasts vary in size from a few $\mathrm{cm}$ to $0.75 \mathrm{~m}$ in diameter. Boulders/clasts are mostly (sub)rounded although rarely some angular clasts occur. The Division I conglomerate/breccia is clast supported with a sparse matrix (referred to as Facies A, Fig 7A). Matrix is composed of marl, small lithoclast fragments and foraminiferal debris (nummulitid and orthophragminid tests). The major lithological components are Cretaceous limestones (88\%) while Foraminiferal limestones (9\%) and other constituents $(3 \%)$ are less abundant. Interestingly, the Lower Cretaceous limestone clasts were only observed in this megabed. The clast composition is presented in Fig. 3B and selected photomicrographs of Lower-, Upper Cretaceous and Foraminiferal limestone clast microfacies are presented in Plate $1 \mathrm{E}, \mathrm{F}$, and $\mathrm{G}$.

Division II is composed of normally graded calcirudite and calcarenite with the following composition: orthophragminids (32-54\%), nummulitids (6-26\%), and red algae (9-13\%), as pre-

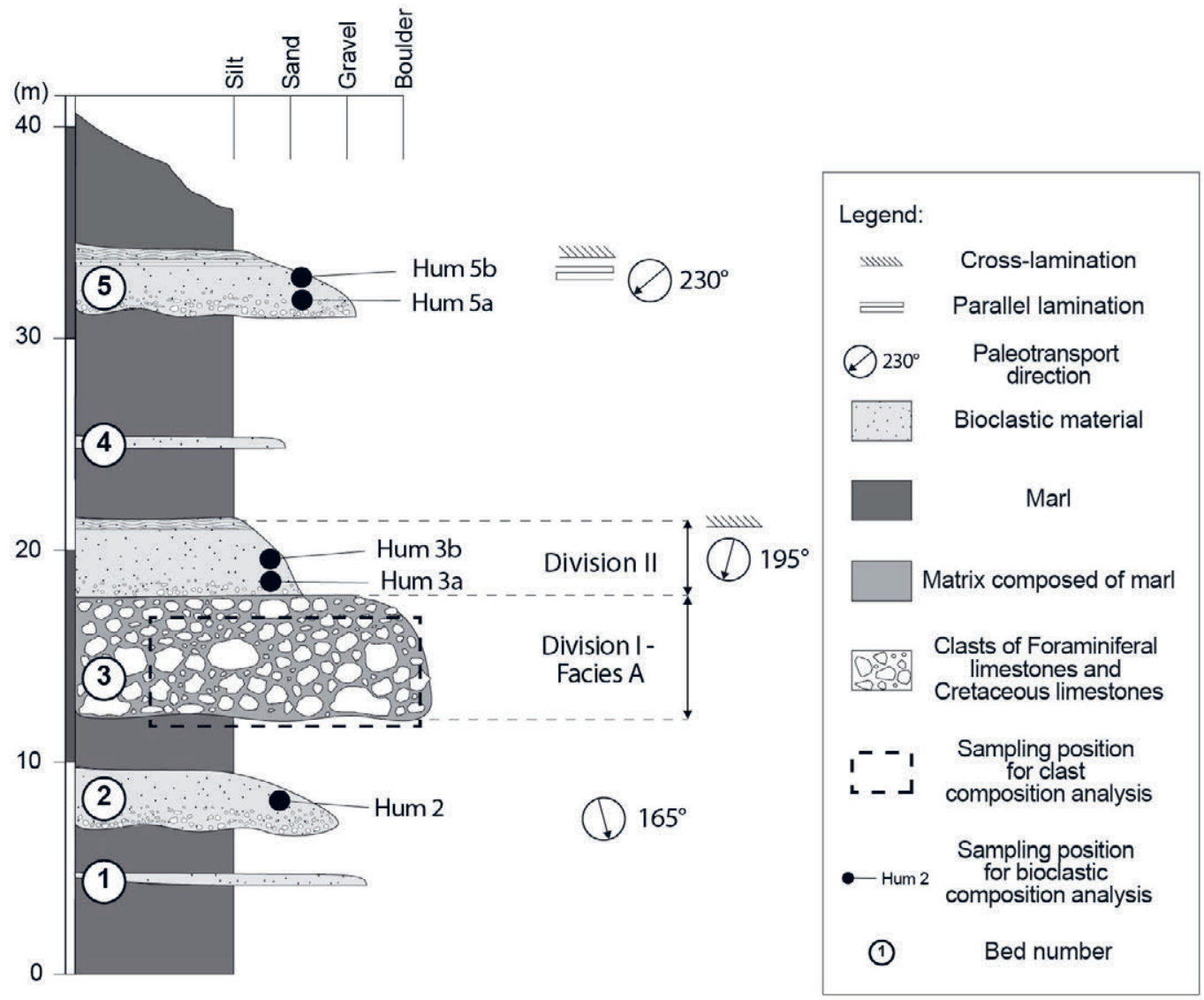

Figure 6. Geological column showing the $10 \mathrm{~m}$ thick Hum megabed (3) and carbonate turbidites (1, 2, 4 \& 5). 

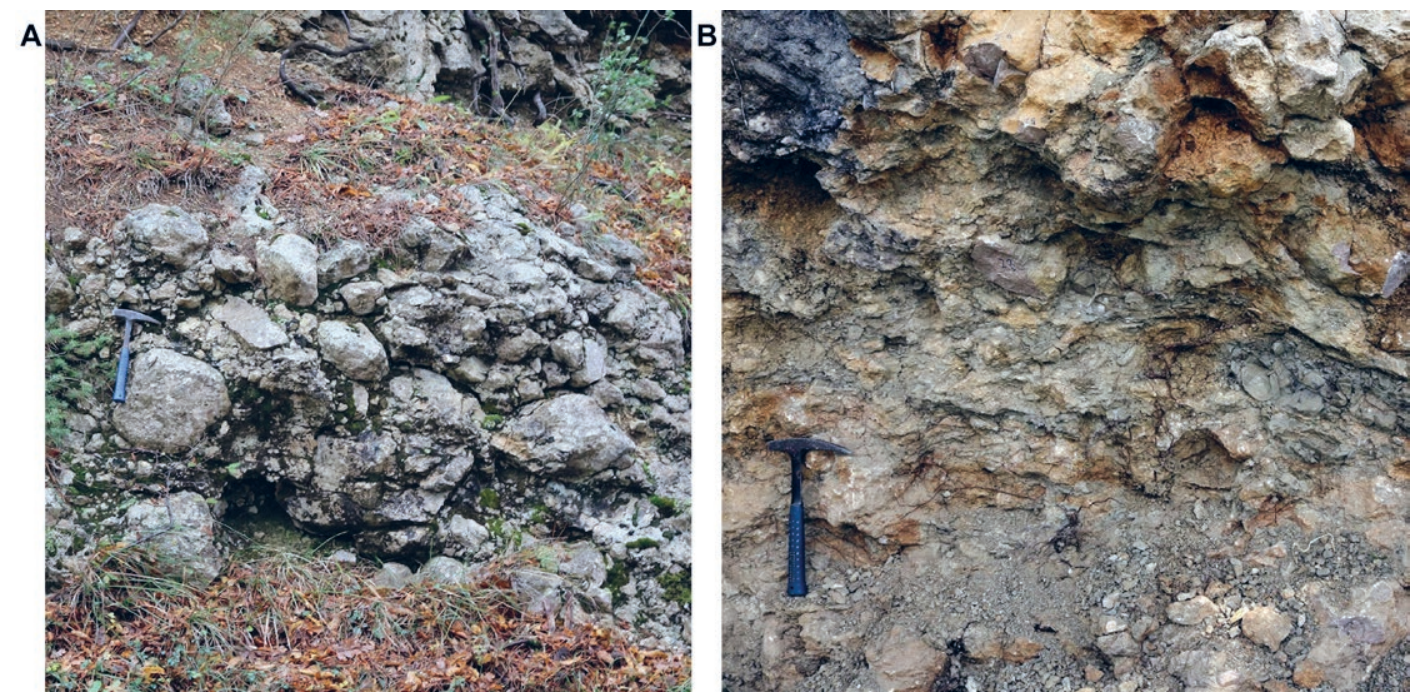

Figure 7. The outcrop photographs of the Division I deposits, showing clast supported breccia with sparse marl matrix (Facies A). (A) Hum megabed Division I clast supported breccia/conglomerate with sparse matrix; (B) Plomin megabed Division I - clast supported breccia with sparse marl matrix. The geological hammer is $32 \mathrm{~cm}$ long.

sented in Table 1. The Hum 2 and 5 beds are also composed of normally graded calcirudite and calcarenite with the same main constituents, but in different proportions (Table 1).

Based on the uniform composition, it is assumed that the carbonate detritus source for the turbidites (Hum 2 and 5), and megabed (Hum 3) was the same. A palaeotransport direction of $165^{\circ}$ was measured from flute casts observed on the lower bedding plane of the Hum 2 turbidite (Fig. 6), and $195^{\circ}$ on ripple marks observed on the upper bedding plane on the Hum 3 mega-

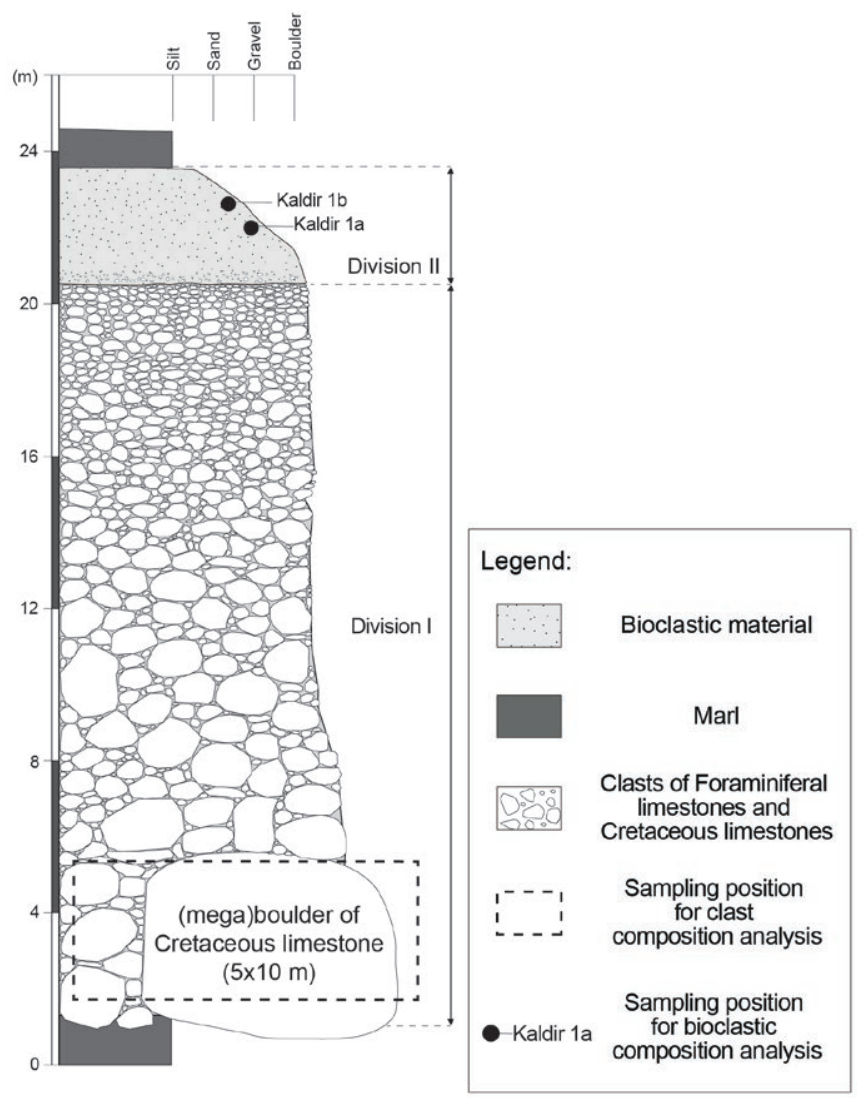

Figure 8. The Kaldir megabed column. bed, and $230^{\circ}$ on turbidite Hum 5 (Fig. 6). These data, though insufficient for statistical assessment, indicate that palaeotransport of the more proximal megabeds was locally generally towards the $\mathrm{S}$, as measured in the Hum Section (Fig. 6).

\subsection{The Kaldir Section}

The studied outcrop of the Kaldir megabed is located near Kaldir village (Fig. 1, WGS84 coordinates: lat $45^{\circ} 18^{\prime} 43.1598^{\prime \prime}$, long $13^{\circ}$ $51^{\prime} 16.9056$ "). This megabed (Fig. 8) is approximately $25 \mathrm{~m}$ thick, composed of limestone breccia (Divison I) in the lower part and the normally graded calcirudite/calcarenite in the upper part (Division II). The geographic distribution of the Kaldir megabed is shown on Fig. 9. When compared to the other megabeds, the Kaldir Division I displays a significant difference in clast size and shape and very low marl content. The contact between the Kaldir megabed and the underlying marl is sharp and erosional. The largest clast lies directly on the underlying marl at the bottom of the sequence and has a visible dimension of $5 \times 10 \mathrm{~m}$ (Fig. 10A). The breccia is clast supported, unsorted with a sparse matrix composed of fine-grained rock debris. Clasts are angular, indicating short transport distances. A normal gradation is visible towards the upper part of Division I. The clast composition is as follows: Upper Cretaceous limestones $90 \%$, Foraminiferal limestones $9 \%$, and undetermined clasts $1 \%$. Also, a bauxite clast was observed. The composition is presented in Fig. 3C, while clast microfacies of Upper Cretaceous and Foraminiferal limestones are presented in Plate $2 \mathrm{~A}, \mathrm{~B}, \mathrm{C}$. The majority of the Foraminiferal limestone clasts are classified as Discocyclina limestones. Some of the Discocyclina limestone intraclasts (plasticlasts) are plastically deformed between the larger Cretaceous boulders and are tightly packed (Fig. 10B). This phenomenon indicates that some of the Discocyclina limestones were not fully consolidated during their resedimentation and deposition in the breccia. The transition to a normally graded $3 \mathrm{~m}$ thick calcirudite/calcarenite (Division II) unit is gradual. The most common constituents of bioclastic material are: orthophragminids $(35-41 \%)$, red algae (23-24\%), and rotaliid foraminifera including hyaline fragments $(14 \%)$. The proportions of all constituents in the investigated samples are shown in Table 1 and illustrated in Plate 2D. 


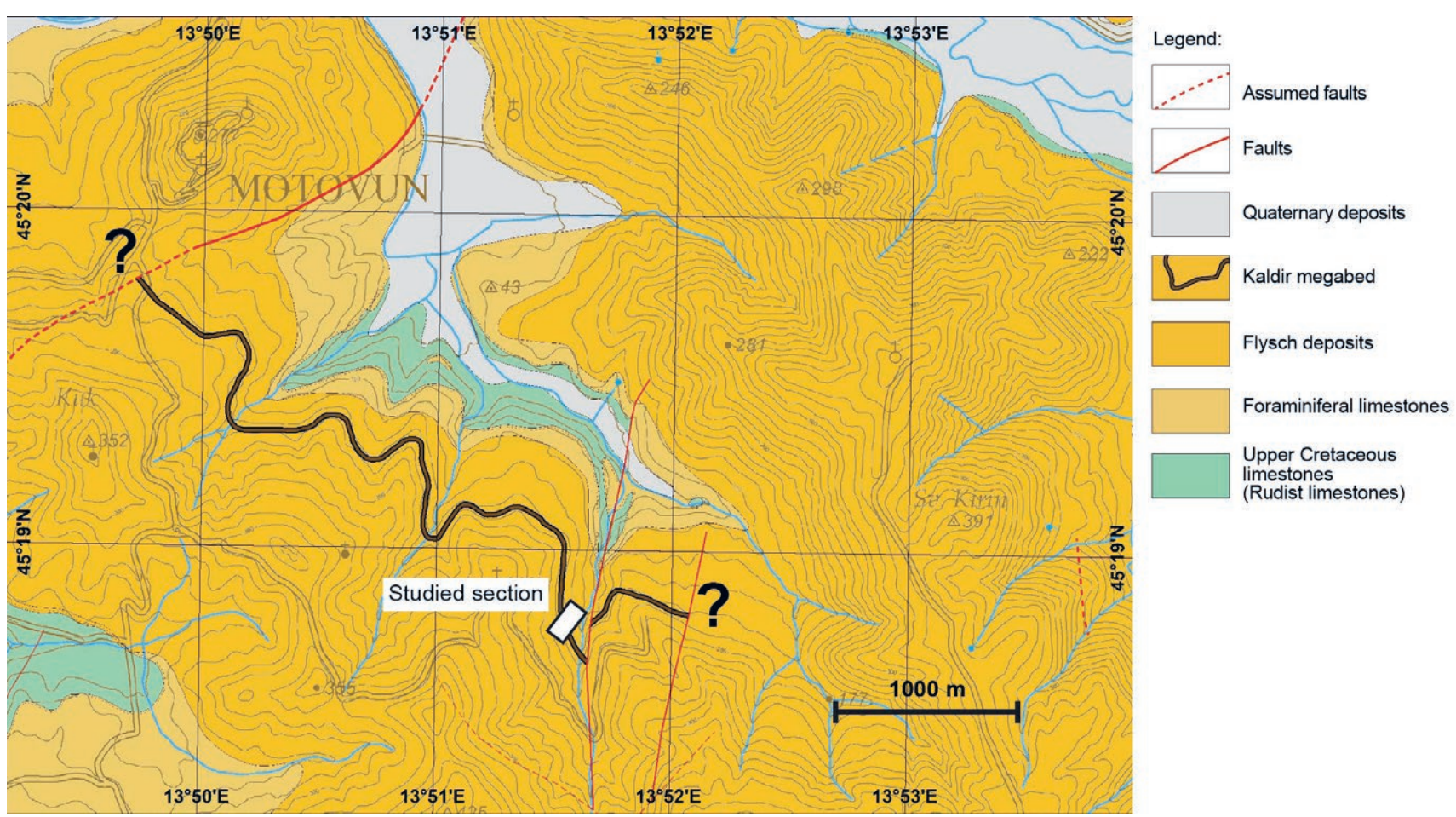

Figure 9. Geological map showing the Kaldir megabed spatial distribution, modified after BERGANT et al. (2020).

\subsection{The Gračišće Section}

The Gračišce megabed is located south-east of the town of Gračišce (WGS84 coordinates: lat $45^{\circ} 12^{\prime} 59.6844^{\prime \prime}$, long $14^{\circ} 0$ 0' 29.7', Fig. 1). The contact with the underlying marls is covered by vegetation and the lower bedding surface of the Gračišce megbed is therefore not visible. The megabed is a bipartite bed with chaotic breccia (Division I) that is matrix supported (referred to as Facies B) in the lower part and a well cemented, normally graded calcirudite/calcarenite in the upper part, with a total thickness of $40 \mathrm{~m}$ (Fig. 11). The lower breccia interval is $25 \mathrm{~m}$ thick, lenticular in shape, and pinches out laterally. This breccia is matrix supported with predominantly sub-angular clasts (Fig. 12A). The most abundant clasts are Foraminiferal limestones (75\%) and marl clasts (17\%), while rhodolith fragments (3\%), Upper Cretaceous limestones (2\%), un- differentiated Cretaceous limestones (1\%), Transitional beds (1\%) and undifferentiated clasts (1\%) are less represented. The composition is presented in Fig. 3D and the selected Algal foraminiferal limestone clast microfacies photomicrograph is presented in Plate 2E. The matrix is a mix of marl, fragmented bioclasts and smaller lithoclasts. Bioclasts are mostly foraminiferal debris (nummulitids and orthophragminids) and rhodoliths. Most clasts are $<10 \mathrm{~cm}$ diameter, while marl clasts are significantly larger and can be up to $50 \mathrm{~cm}$ across (Fig. 12B). The Division I breccia gradually transitions into a well cemented, normally graded calcirudite/calcarenite in the upper part of the section. The most common constituents of Division II material are: orthophragminids (31-35\%), nummulitids (11-25\%), red algae (17-20\%), and lithoclasts (8-16\%). The ratios of all constituents in the investigated samples are shown in Table 1 and illustrated in Plate 2F.
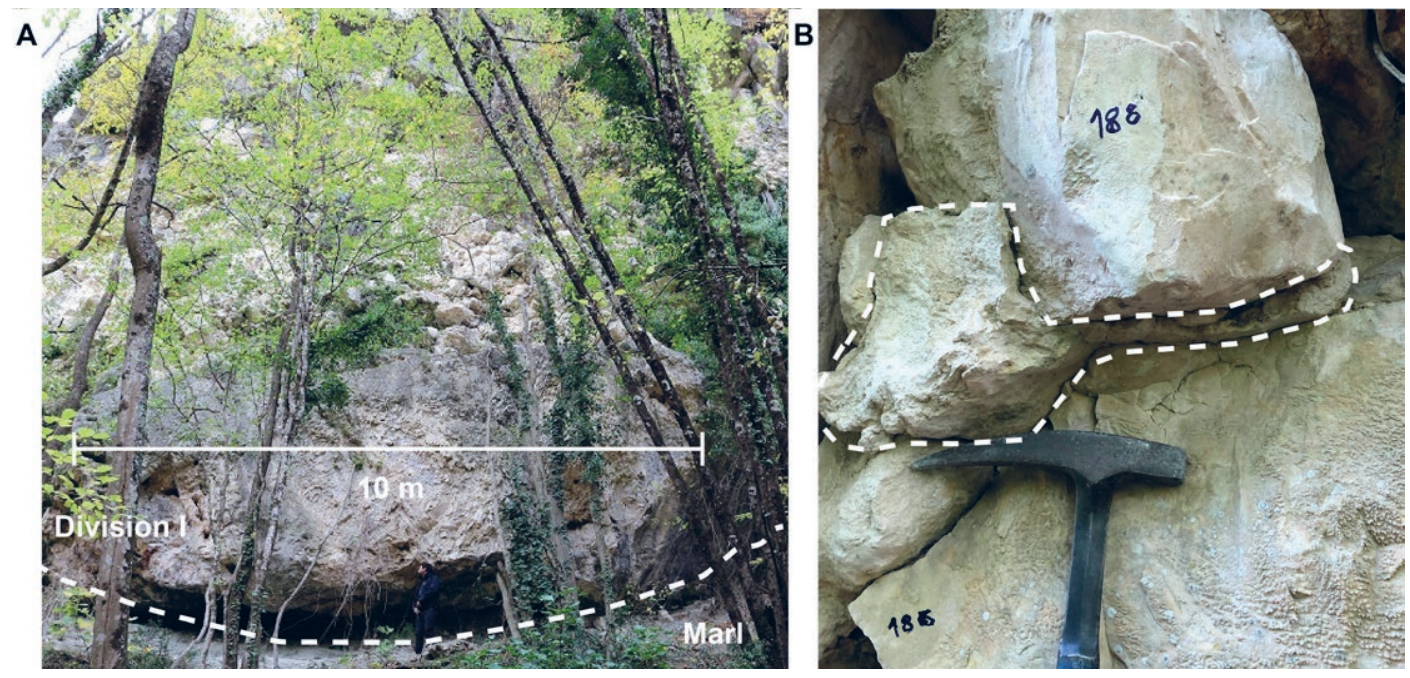

Figure 10. The Kaldir Division I breccia. (A) The 10x5 m boulder of the Upper Cretaceous limestone in the base of the Kaldir megabed. The contact between the Kaldir megabed and the underlying marls is sharp and erosional. (B) The Discocyclina limestones occur as plastically deformed clasts compressed between the larger Cretaceous clasts. The geological hammer head is $19 \mathrm{~cm}$ long. 


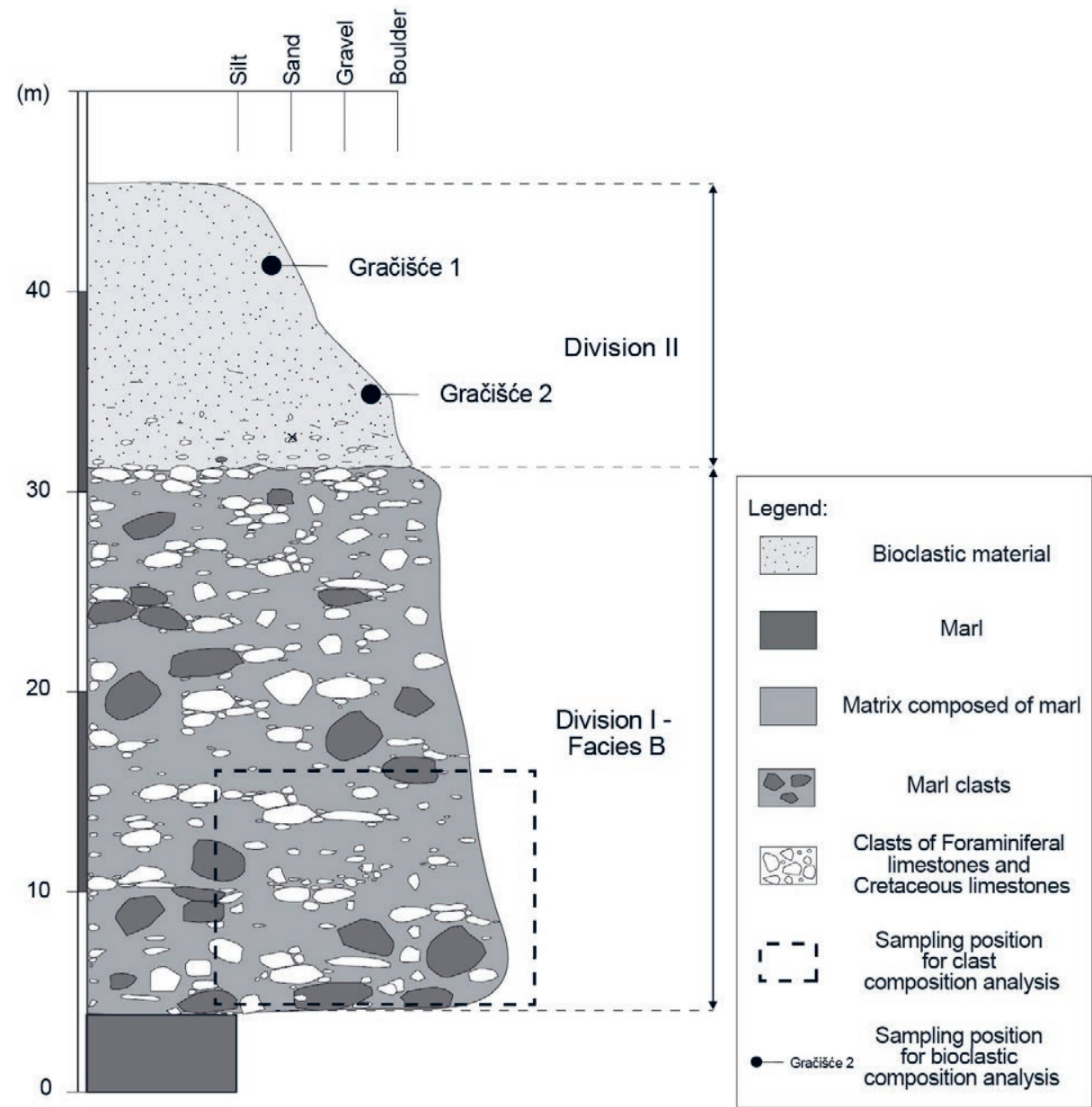

Figure 11. The Gračišće megabed column.

\subsection{The Plomin Section}

The Plomin megabed crops out on the road cut NW of Plomin village (WGS 84 coordinates: lat $45^{\circ} 8^{\prime} 45.6612$ ", long $14^{\circ} 10^{\prime}$ 19.5198"). As a consequence of tectonic deformation along the nearby N-S striking fault (Fig. 1) the beds are relatively inclined with average bed dip azimuth and dip angle of 150/40. The lower part of the Plomin megabed and the contact with the underlying marls is covered by vegetation and colluvium. The studied bed is composed of a $3 \mathrm{~m}$ thick Division I breccia in the lower part (Fig. 7B) and $17 \mathrm{~m}$ of normally graded bioclastic calcirudite/calcarenite in the upper Division II (Fig. 13). The breccia is composed of boulder-sized clasts with an average longer axis of $20-30 \mathrm{~cm}$. The largest measured clast is $50 \mathrm{~cm}$ in diameter. The lithological composition of the breccia is Foraminiferal limestones $93 \%$, Transitional beds $2 \%$, marl $2 \%$, and undetermined clasts $3 \%$. The
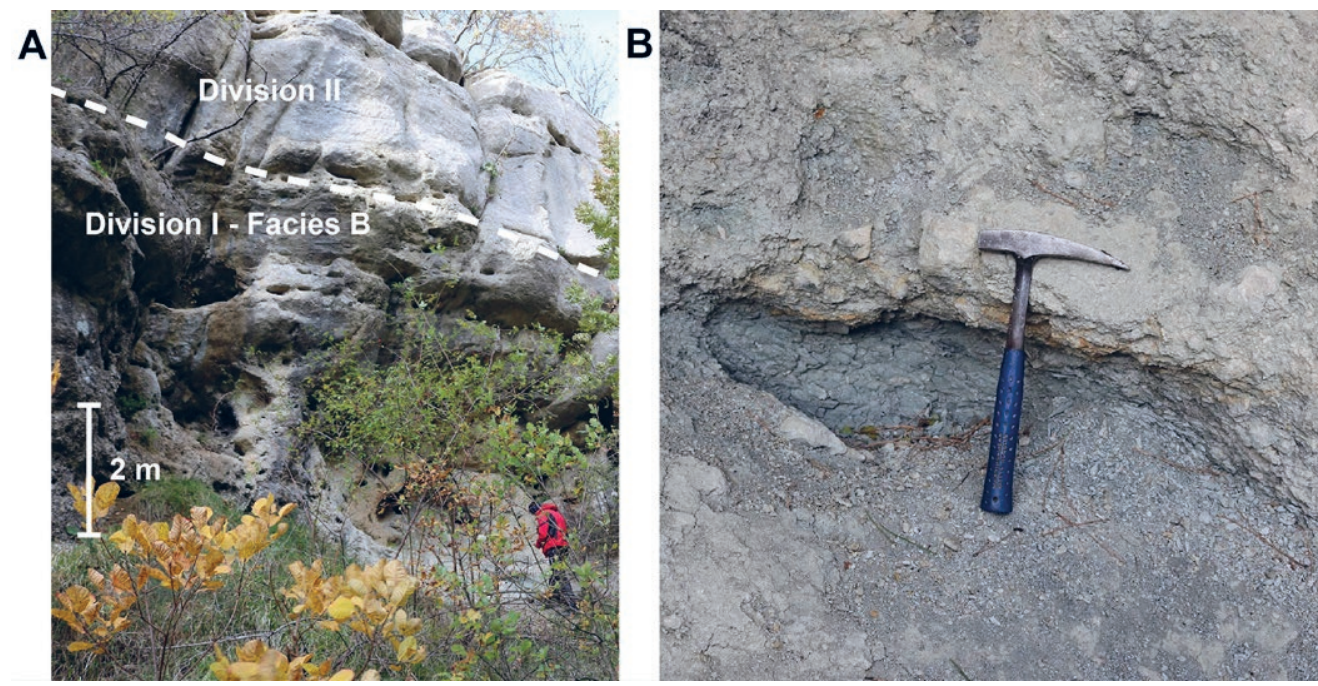

Figure 12. Photographs of the Gračišće megabed (A) The outcrop of the Gračišće megabed with marked divisions. The holes (casts) within Division I are formed because of the selective erosion of marl clasts. (B) Photographs of marl clasts within Division I, Facies B of the Gračišće megabeds. The marl clasts are significantly larger than the limestone clasts. The geological hammer is $32 \mathrm{~cm}$ long. 
clast composition is presented in Fig. 3E and selected photomicrographs of Foraminiferal limestone clast microfacies are presented in Plate 3A, B, and C. The breccia is mostly clast supported, with a sparse matrix. The matrix is a mix of marl, fragmented bioclasts and smaller lithoclasts. Bioclasts are mostly foraminiferal debris (nummulitids and orthophragminids) and rhodoliths. The carbonate breccia (Division I, Facies A) gradually transitions to a $17 \mathrm{~m}$ thick normally graded calcirudite/calcarenite (Divison II) and the matrix content decreases. Calcirudite is a well cemented, normally graded bed without a marl matrix, with a maximum clast size of $10 \mathrm{~cm}$ in diameter. The most common constituents of bioclastic material are ortophragminids (35\%), nummulitids (27-33\%), lithoclasts (11-12\%), and red algae (7-18\%). The proportions of all constituents in the investigated samples are shown in Table 1 and illustrated in Plate 3D. Marl clasts occur in the middle part of the calcirudite zone, have an elongated shape, parallel orientation, and are 30-40 cm long and up to $6-10 \mathrm{~cm}$ thick. The size of the marl clasts gradually decreases towards the upper part of the calcirudite zone. Calcirudite gradually transitions to calcarenite (normal gradation) with visible parallel lamination and indistinct cross lamination unsuitable for palaeotransport measurements. The upper part of this megabed ends with a massive marl interval. The Plomin megabed is overlain by an interval of about $20 \mathrm{~m}$ of continuous Flysch, composed of marl and thin carbonate and mixed carbonate and siliciclastic turbidites.

\subsection{The Koromačno Section}

The Koromačno section of the Istrian Flysch is located in Koromačno quarry (WGS84 coordinates: lat 44 58' 10.8366", long $14^{\circ} 7^{\prime}$ 53.94"). Besides Division I and Division II, a Transitional zone is outlined in the Koromačno megabed (Figs. 14 and 15A). The Transitional zone has characteristics of both the lower Division I and upper Division II. The characteristics of Division I are large marl clasts (largest measured clast with long axis of 1 metre). The similarity with the upper Division II is the composition of a distinctly graded calcirudite fabric. The lower bedding surface of the Koromačno megabed is not exposed at this location, but underlying calcarenite and marl beds are recognized in the vicinity.

The lower Division I (Facies B, Fig 15B) interval is composed of a matrix supported breccia with large clasts of marl and limestone lithoclasts. The clast composition is: Foraminiferal limestones $80 \%$, Transitional beds $3 \%$, marl clasts $16 \%$, and undetermined clasts $1 \%$. The clast composition is presented in Fig. $3 \mathrm{~F}$ and selected Foraminiferal limestone clasts microfacies photomicrographs are presented in Plate 3 E, F, and G. As in the Gračišće megabed, the matrix is a mix of marl and fragmented bioclasts (nummulitids and orthophragminids and rhodoliths).

In the middle part, labeled as the Transitional zone, the content of the marl matrix rapidly decreases and well cemented cal-

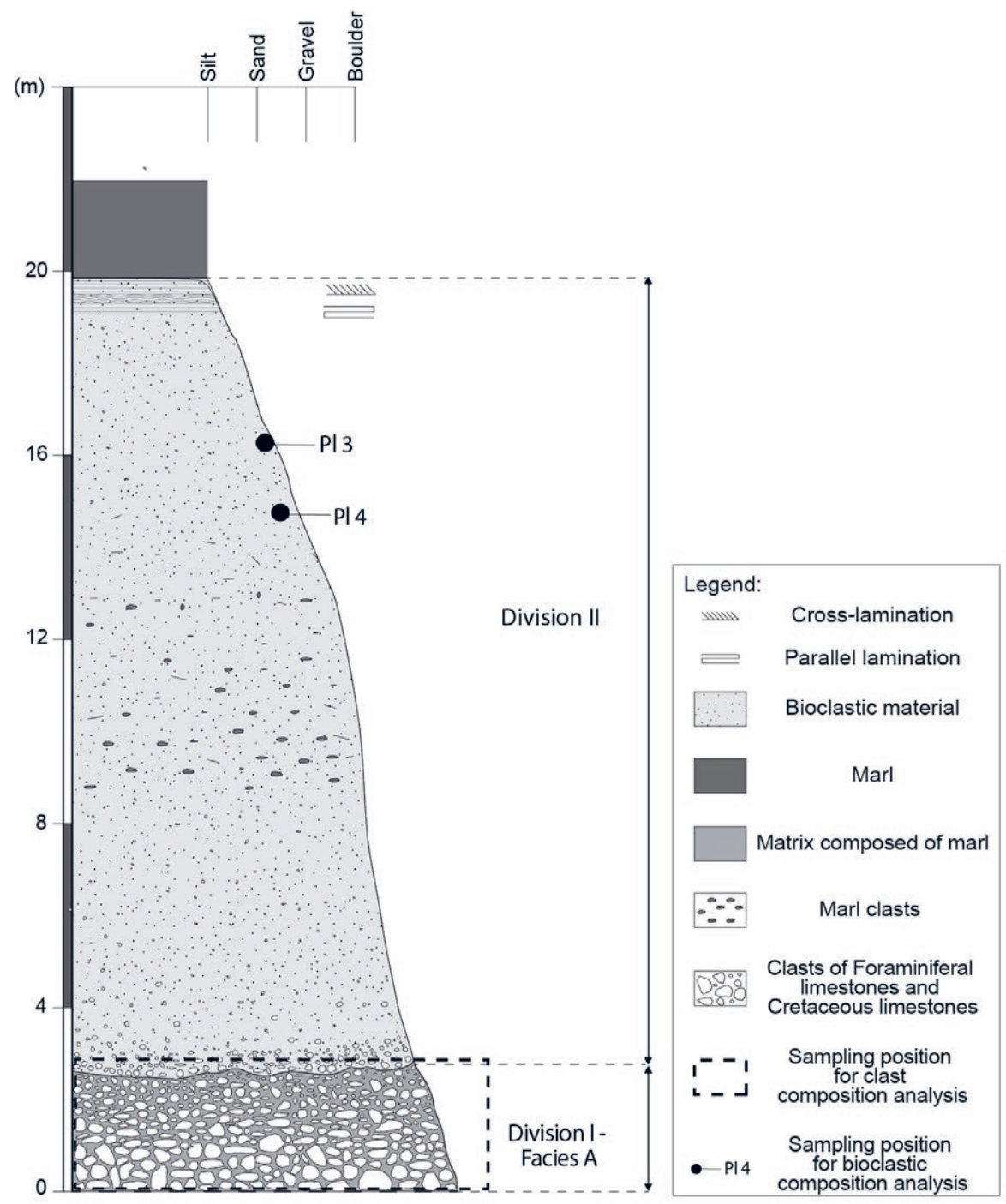

Figure 13. The Plomin megabed column. 

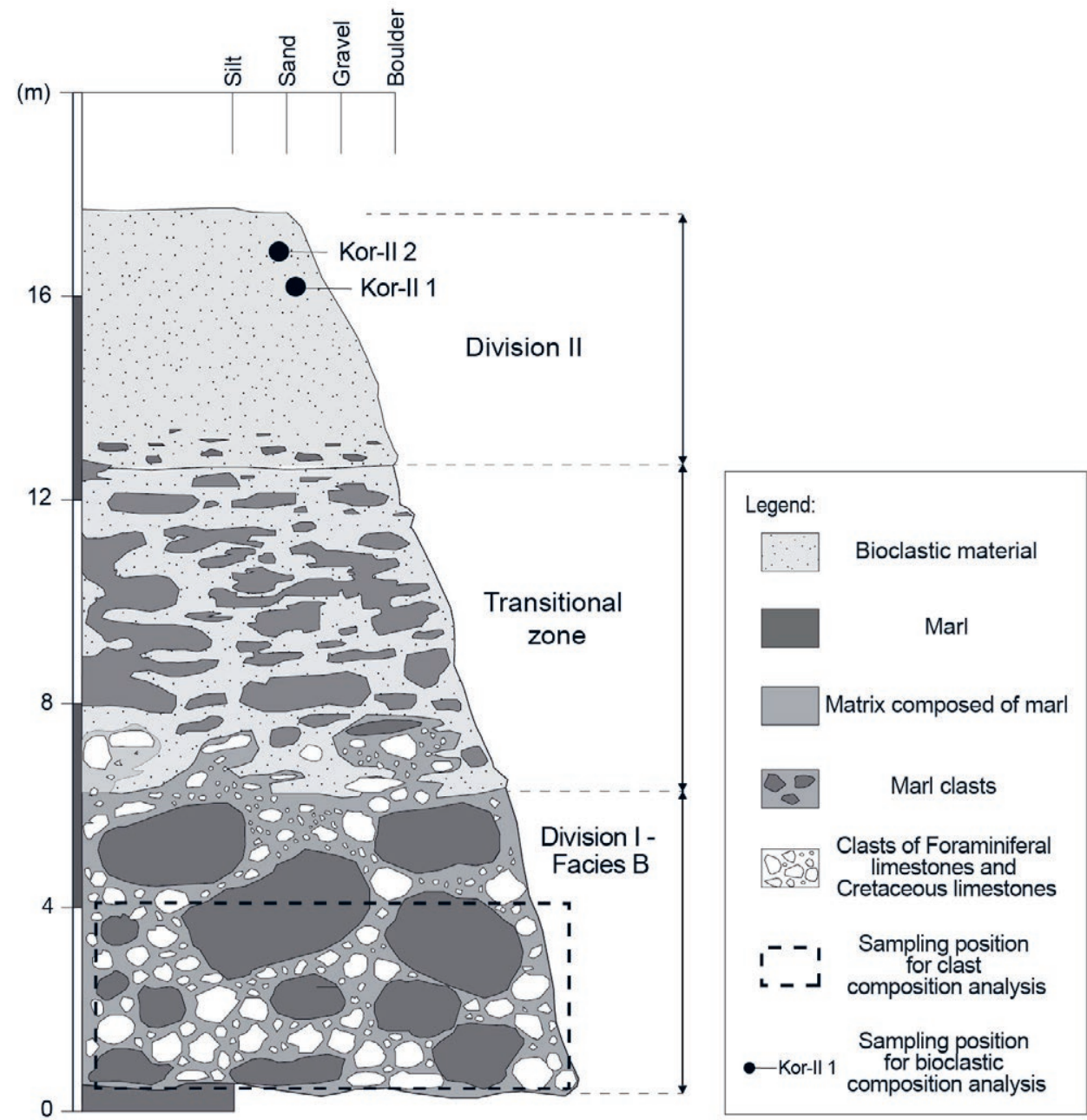

Figure 14. The Koromačno megabed column.

cirudite becomes dominant. The largest clasts are outsize marl clasts with long axis dimensions of $1 \mathrm{~cm}$ to $1 \mathrm{~m}$. Marl clast size decreases up-section. Transitions between these parts are gradual. The Division II interval follows the Transitional zone and is marked by the absence of marl clasts. It is composed of normally graded calcirudite and calcarenite. The most common constituents of Division II material are: red algae (28-31\%), lithoclasts (22-27\%), orthophragminids (16-21\%), and nummulitids (13\%). The ratios of all the constituents in the investigated samples are shown in Table 1 and illustrated in Plate $3 \mathrm{H}$.

\section{INTERPRETATIONS}

The studied beds are bipartite, composed of debris flow deposits in the lower part (Division I) with a gradual transition to a highdensity turbidity current deposit in the upper part (Division II).

\subsection{Division I}

Within Division I two facies types are recognized and both are interpreted as debris-flow deposits that suggest "en masse" deposition after cohesive freezing.

Facies A is a clast supported conglomerate/breccia, normally graded, with sparse matrix. This facies is observed at the Hum, Plomin, and Šublentica sections. The lithological composition of the clasts is different in each of the investigated beds (Fig. 3). The marl (rip-up) clasts in Facies A are found only in the Plomin section. Weak normal grading is recognized in the upper part of the division at the Hum and Sublentica sections. The matrix is com- posed of marl and bioclasts, mostly nummulitids and orthophragminids.

Facies B of Division I is a chaotic, matrix-supported breccia with outsized rip-up clasts, and a greater total thickness than Facies A. The characteristic by which the described facies are distinguished is the amount of matrix and the marl content. Facies $\mathrm{B}$ is observed at Koromačno and Gračišće. The matrix is a mix of marl, fragmented bioclasts and smaller lithoclasts. Bioclasts are mostly foraminiferal debris (nummulitids and orthophragminids) and rhodoliths.

The bipartite organization is a consequence of the transformations from debrite flow to turbidity current, as the debris flows are considered to be one of the mechanisms for generating turbidity currents (HAMPTON, 1972; LOWE, 1982; MULDER \& ALEXANDER, 2001; SHANMUGAM, 2006; FELIX et al., 2009). Facies A deposits are related to clast-dominating debris flows, while Facies B deposits are related to more marl (mud) rich debris flows. Observed differences in the matrix and the marl content might be related to differences in the initial composition of the mass flow and the evolution of the flow.

The Division I at Kaldir megabed is singled out for its unique properties: total thickness, clast size and angular shape, and total lack of matrix. The clast size (largest measured clast is 5x10 m) and angular clast shapes suggest a very short transport distance. The lack of matrix indicates a transport mechanism different to a cohesive debris flow, probably a large-scale submarine rockavalanche. 

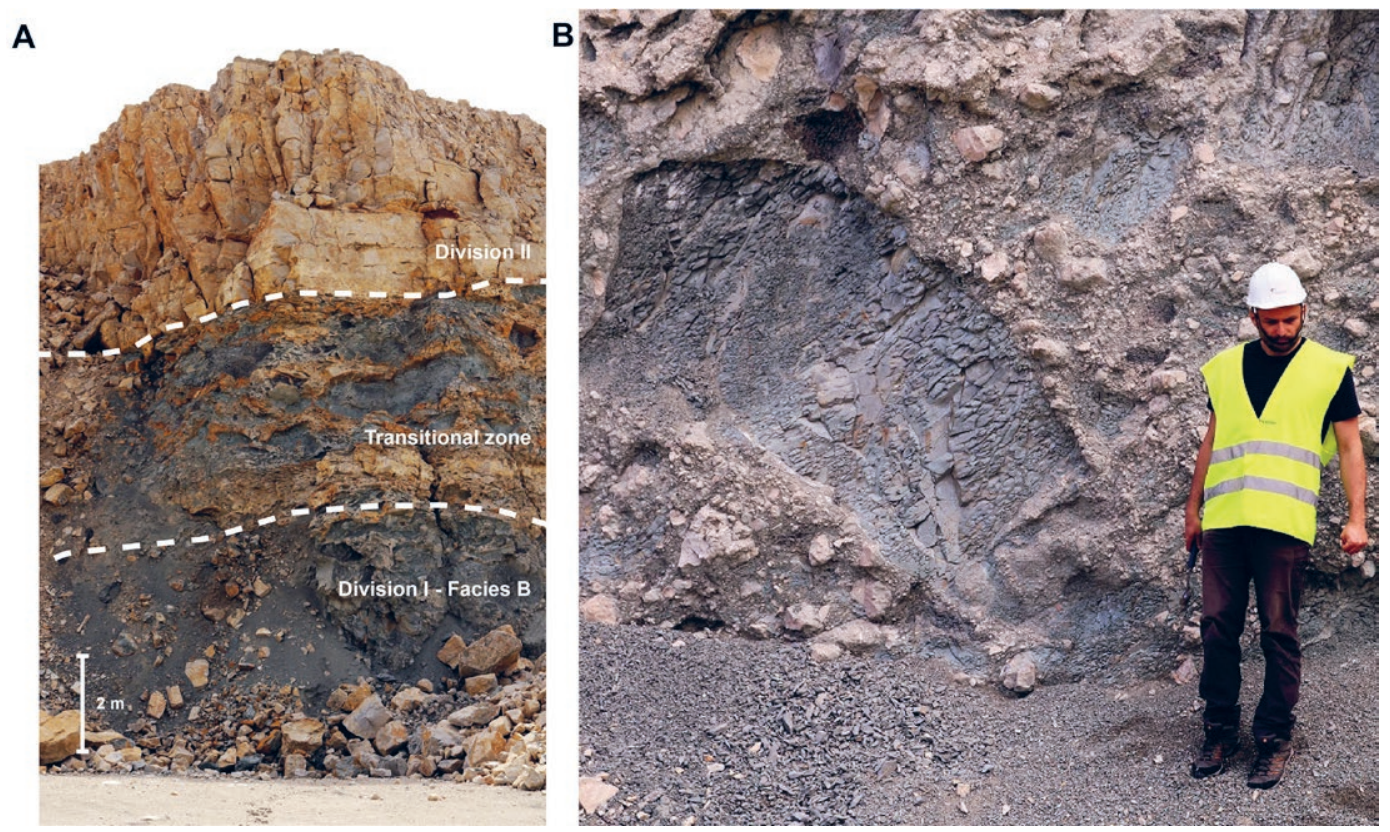

Figure 15. (A) Outcrop of the Koromačno megabed showing two divisions and a transitional zone in the middle. The chaotic, matrix supported breccia in the lower part (Division I) gradually transitions into the transitional zone, composed of cemented calcirudite breccia with large marl clasts (Transitional zone). The normally graded calcirudite lacking outsized marl clasts is located at the top (Division II). (B) Marl clast within Division I breccia, Facies B part of Koromačno megabed. The clast dimension is $2 \times 1 \mathrm{~m}$ at outcrop.

\subsubsection{The composition of Division I clasts}

The studied clast composition indicates that Division I material (clasts) was derived from different parts of the Cretaceous to Palaeogene neritic carbonate succession that underlies the Eocene Flysch. The most common clasts determined in each megabed, categorized according to the previously defined major lithostratigraphic units, are Foraminiferal limestones and Upper Cretaceous Rudist limestones, as shown in Fig. 1. The Lower Cretaceous clasts are only observed in the Hum megabed. Rare bauxite and karstified Cretaceous limestone clasts were only recognised in the Kaldir megabed. The karstified Upper Cretaceous limestone boulder with bauxite karst infills has been described by TARLAO et al., (1995) in a debrite within the Istrian Flysch southwest of Pazin (Fig. 1). The palaeo-karstified Cretaceous limestones and bauxite clasts are related to the regional unconformity within the Adriatic Carbonate platform succession that was formed during the Late Cretaceous and Early Palaeogene emersion of the forebulge (OTONIČAR, 2007).

\subsection{Division II}

Division II intervals are up to $10 \mathrm{~m}$ thick, clast supported, and normally graded, calcirudite/calcarenites and are seen in all the studied megabeds. Towards the top of the interval there is a gradual transition, first from calcirudite to calcarenite, and eventually to calcisiltite grain size. In the uppermost part of Division II, horizontal and cross lamination are observed in calcarenites or calcisiltites in the Hum and Plomin megabeds. Division II is overlain by a massive marl deposited from the turbidity current tail. Division 2 of the megabeds is interpreted as a co-genetic turbidite deposited by a high- to low-density current (LOWE, 1982).

\subsubsection{The composition of Division II}

As result of point-counting calcirudite/calcarenite samples of the Division II interval, 12 different constituents are distinguished and grouped. The results of Division II composition analysis (Table 1) shows that the most abundant grains in Division II are or- thophragminids, nummulitids, red algae, and lithoclasts. This specific composition shows a clear predominance of bioclastic material derived from the outer carbonate ramp environments as described in Eocene carbonate ramp models in HALLOCK \& GLENN (1986), ĆOSOVIĆ et al. (2004), and BASSI (2005). The coralline rhodolites were probably formed along intrabasinal, isolated banks, characterized by strong water currents and reduced sediment input (RASSER \& PILLER, 2004; BARATTOLO et al., 2007). The lithoclasts observed are grains of older limestone rocks from the Cretaceous-Palaeogene limestone succession (extraclasts). The most abundant extraclasts are mudstones or wackestones containing sparse unidentifiable bioclasts. The matrix is micrite (Group 2), while sparite cement is scarce (Group 3). The Large benthic foramniferal taxa are assigned to groups 4, 5 and 11. The other skeletal grains are grouped according to their taxa. The calcirudite and calcarenite microfacies of Division II with some of the most abundant constituents is presented in Plate I D, H, Plate II D, F and Plate III D, H.

\section{DISCUSSION}

\subsection{Palaeotransport directions}

In the palaeotransport model for the Pazin (Istrian) Basin provided by BABIĆ \& ZUPANIČ (1996), the palaeotransport direction of carbonate beds composed of debrite and turbidite unit is towards the NNE. Also, BABIĆ \& ZUPANIČ (1996) suggest the existence of land and shelf environments to the SSW of the former Pazin Basin from where the carbonate material was derived. Since the data about the palaeotransport directions found in the studied megabeds is scarce, we can assume that the major source of carbonate material were fault dissected or a locally over steepened distal foredeep slopes (cf. SINCLAIR, 1997; BARNOLAS \& TEIXELL, 1994), that were located along the southern margin of the Istrian Flysch basin, as proposed by BABIĆ \& ZUPANIČ (1996). According to that model, all the studied megebeds were deposited by gravitational flows on the distal slopes of the foredeep, along the 
transitional zone between the basin and the distal carbonate ramps to the $\mathrm{S}$, indicating the transport was towards the $\mathrm{N}$.

However, palaeotransport measurements within this study were derived from only one megabed on the Hum section and two from the thick carbonate turbidites in the succession (Fig. 6). According to this data the paleaotransport of more proximal megabeds was locally towards the $\mathrm{S}$.

Combining the observed data within this study (palaeotransport direction on Hum section) and older research (BABIĆ \& ZUPANIČ, 1996), we can assume that the carbonate detritus had multiple sources and transport directions, with the major transport direction towards the $\mathrm{N}$ and minor transport towards the $\mathrm{S}$ (Figs 16 and 17).

\subsection{The source of shallow-water bioclastic detritus}

Shallow-water bioclastic detritus is a constituent of the studied megabeds and is observed in Division I mixed with marl in the matrix, and as grains of bioclastic calcirudite/calcarenites of Division II. The source area of the bioclastic detritus was a synchro- nous shallow water carbonate ramp attached to Flysch basin from the south (Fig. 16).

Carbonate ramps in a foreland basin setting could be formed on an underfilled foreland basin margin (SINCLAIR, 1997; BOSENCE 2005) or developed on overthrusts and thrust folds, as described in Northern Dalmatia (ĆOSOVIĆ et al., 2018). Since thrusts and thrust-top deposits are not recognized in the northern part of the Istrian Flysch basin, a more probable location for the ramp is in the South, as a distal, marginal (forebulge) part of the Dinaric foreland basin (OTONIČAR, 2007). The distal margin of low-latitude, underfilled foreland basins is a favoured site for the accumulation of large carbonate platforms and ramps (SINCLAIR, 1997; BOSENCE 2005). Alternatively, it can be argued that the bioclastic detritus originated from stratigraphically older, weathered Foraminiferal limestones. If that were the case, its composition would include fossils from other Foraminiferal limestone strata, e.g. alveolinid or miliolid tests, but no such grains were recognized in this study. The absence of these characteristic foraminifera lead to the conclusion that the bioclastic detritus came from synchronous outer-ramp environments that were attached to the Istrian Flysch basin from the South. However, there is also the

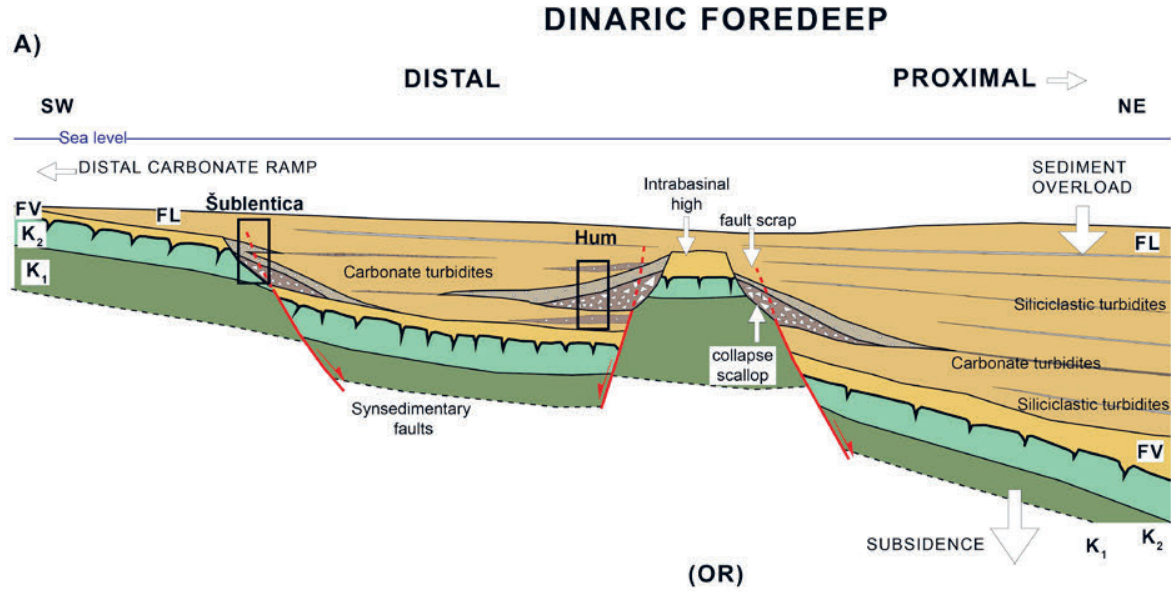

DINARIC FOREDEEP

B)

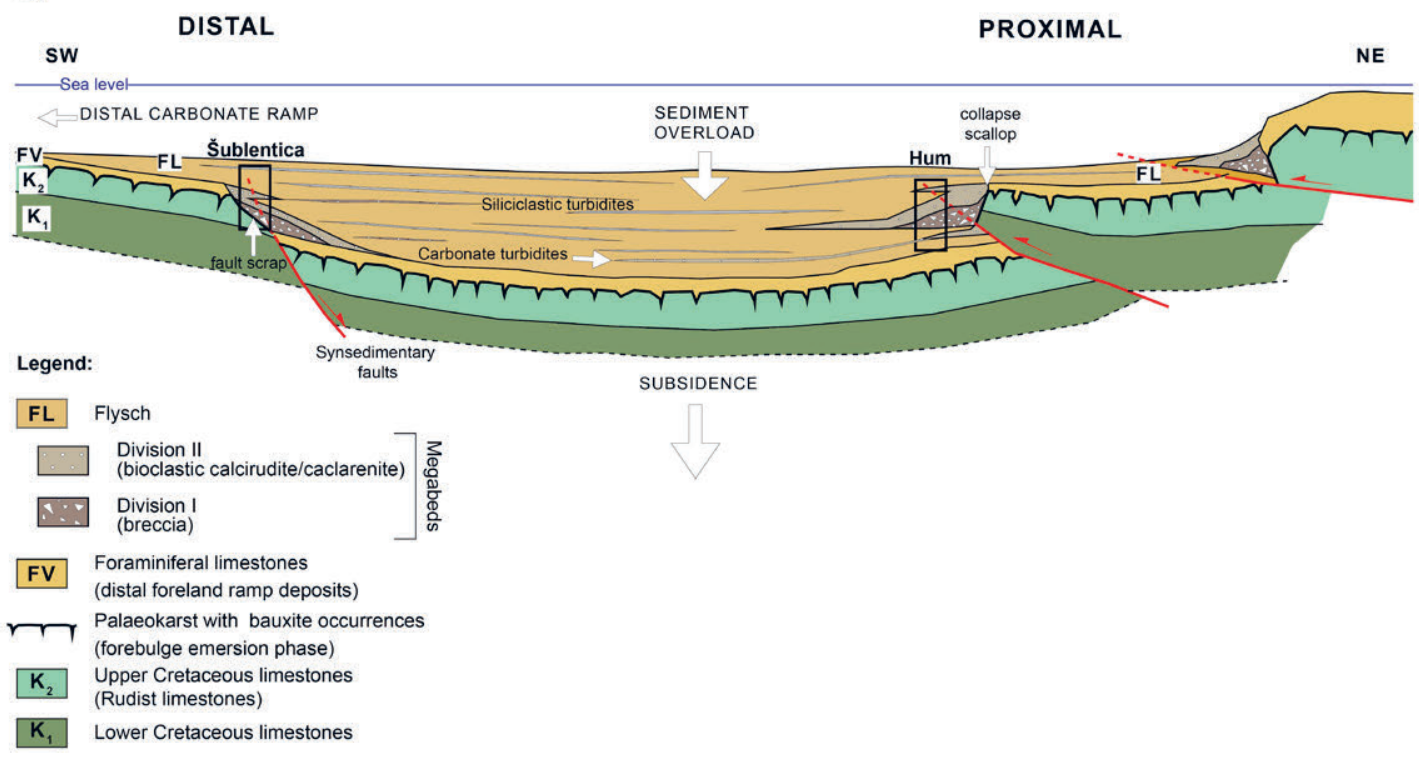

Figure 16. Two possible options of schematic reconstructions of the Istrian foredeep basin after megabed deposition. (A) All megabeds are related to extensional tectonics and normal faulting in the distal foredeep. (B) Proximal megabeds are related to compressional tectonics and reverse faulting in front of the Dinaric orogenic wedge. Not to scale. See discussion in the text. 
possibility that some bioclasts originally originated from the outer ramps are derived from semi-consolidated (uncemented) clayey limestones from the collapsed succession along the foredeep slope.

\subsection{Interpretation of the internal divisions and compa- rison with previous works}

As far as sedimentary processes are concerned, the megabeds may be considered as complex beds which were deposited by a range of sedimentary processes e.g., submarine rock avalanche, debris flow, and high-density turbidity currents. As mentioned earlier, the distinct bipartite organization is a consequence of the flow transformations from debrite flow to turbidity current (HAMPTON, 1972; LOWE, 1982; MULDER \& ALEXANDER, 2001; SHANMUGAM, 2006). This distinct architecture can be related to beds with similar internal organization. Comparison with hybrid event beds (HAUGHTON et al. 2003, 2009; TALLING, 2013) indicates that the bipartite megabeds described in this study are lacking the basal layer that is present in tripartite hybrid beds, and are much thicker than the described hybrid event beds in papers by HAUGHTON et al., (2003, 2009) and TALLING (2013). The Division I facies types described here bear comparison with the divisions of megabeds from the published literature. The megabeds described in AMY et al. (2007) from the Piera Cava basin (SE FRANCE) are very similar to the Istrian megabeds described in this research and the authors differentiate two facies types within coarse-grained beds - facies F1: cohesive debris-flow deposit comprised of poorly sorted, metre-long clasts and a significant proportion of muddy matrix; and facies F2: clastrich debris-flow deposits with a minor proportion of cohesive matrix. The carbonate megaturbidites described by LABAUME et al. (1987) from the Eocene Hecho Group (SW-Pyrenean Foreland Basin, Spain) are up to $200 \mathrm{~m}$ thick and composed of a megabreccia unit in the lower part and the turbidite in the upper part. The megabreccia unit is subdivided into separate divisions: a largely clast supported and poorly organized breccia (Division I) and carbonate breccia which contains an abundance of rip-up clasts of slope marlstone and basin plain turbidites (Division II). TUNIS \& VENTURINI (1992) describe megabeds in the Julian basin as couplets of megabreccia in the lower part and a graded calcarenite and marl in the upper part. The described vertical sections of megabeds is further subdivided into two megabreccia units and three turbidite units. Unit 1 is a megabreccia which mainly consists of big blocks of shallow water limestone olistoliths. Unit 2 is also carbonate megabreccia, but can be recognized by the lack of large limestone olistoliths, for the numerous discshaped clasts of calcareous mudstone and for the rip-up siliciclastic turbidites with some interbedded calciturbidites. PAYROS et al. (1999) recognized a downcurrent change in megabed composition from immature, homogeneous debrite in the proximal part, a differentiated, two-storey bipartite debrite and a turbidite in the middle part, and a base-missing debrite overlain by turbidite, or even a turbidite alone, in the distal part. The megabeds containing bipartite breccia outcrops show that each unit consists of a

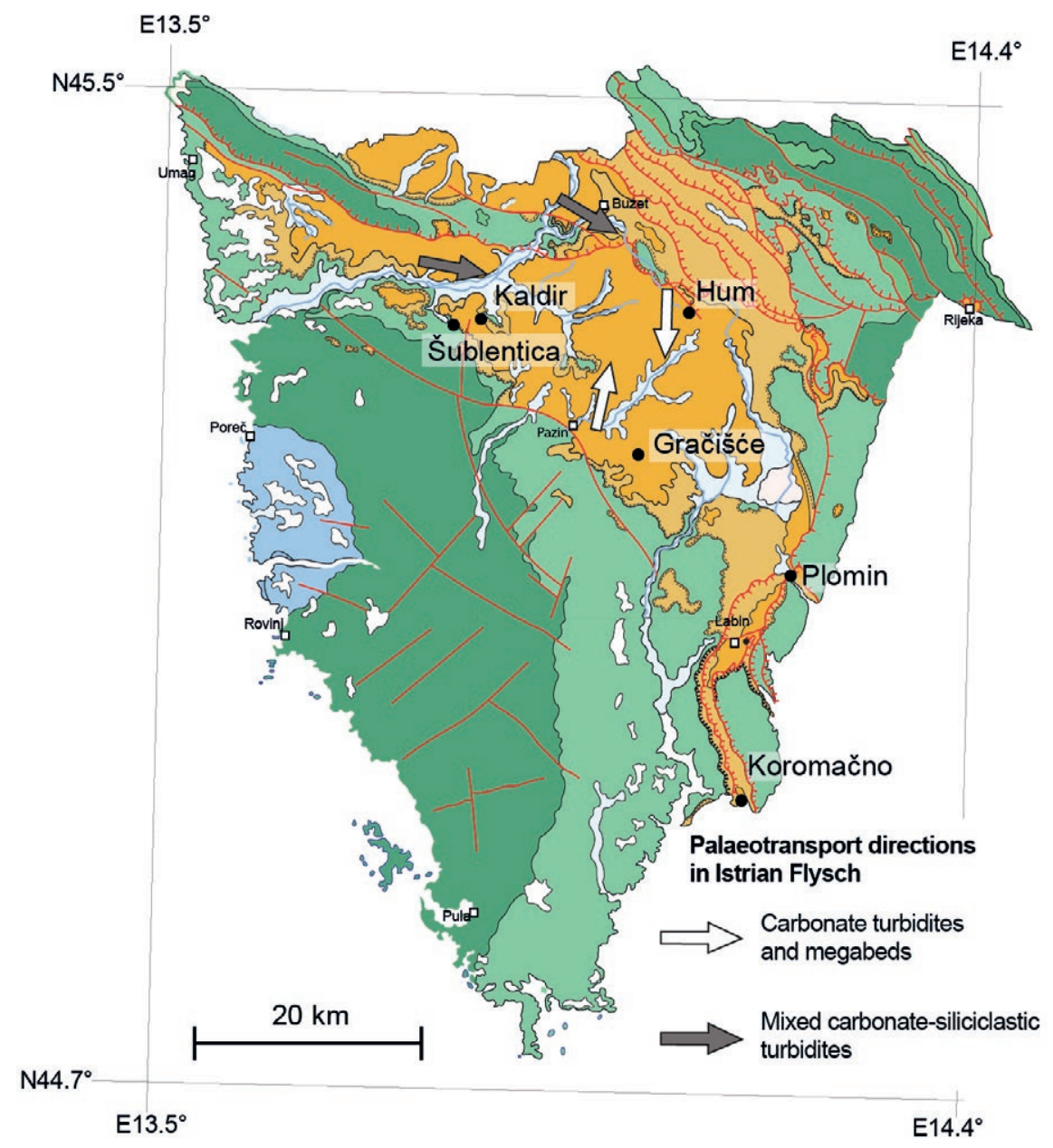

Figure 17. Geological map showing palaeotransport directions in the Eocene Istrian Flysch. The palaeotransport direction data are taken from MAGDALENIĆ (1972), MARINČIĆ et al. (1996) and BABIĆ \& ZUPANIČ (1996). 
clast-supported breccia overlain by a mud-supported breccia and then capped with a graded calcarenite.

To recapitulate, the authors LABAUME et al. (1987); TUNIS \&VENTURINI (1992); PAYROS et al. (1999) describe two subdivisions within a lower, debrite unit: clast supported breccia with olistoliths in the lower part and mud supported breccia containing mudstone rip-up clasts in the upper part. These subdivisions are roughly similar to the Facies A and Facies B described here within Division I. However, within the studied megabeds of the Istrian Flysch, vertical differentiation of facies within Division I itself is not recognized.

The Division I breccia at Kaldir was probably deposited in the early stage of a mass transport event, probably a submarine rock avalanche or some other large-scale grain flow. The dynamic classification of mass transport deposits and evolutionary relationships among the processes responsible for sub-unit formation, from slide/slump and turbidity currents as end-members of such a broad spectrum are described by SHANMUGAM (2006), FESTA et al. (2019) and OGATA et al. (2020). However, the submarine rock avalanche deposits are rarely mentioned in the sedi- ment mass transport spectrum so the exact mechanism of the Kaldir megabed deposition is not yet clear.

HAGN et al. (1979) described the Gračišće olistostrome as containing up to 1 cubic metre sized Cretaceous and Palaeogene boulders, smaller fragments of grey shale and a very rich fossil fauna that lived in the environment of the carbonate shelf. The authors (HAGN et al., 1979) assumed that the fauna and olistoliths originated from different sides of the basin, and that they were resedimented by separate mechanisms and mixed only in-situ, during the final sedimentation. This assumption cannot be maintained because all the biogenic detritus is evenly distributed in the debrite part, as a subordinate constituent of the marly matrix, mixed with larger limestone and marl clasts. Also, the bioclastic detritus is the main constituent in the upper turbitdite part (Division II).

\subsection{Triggering mechanisms and depositional models}

The clast composition indicates that the detritus of each megabed was derived from a different part of the Cretaceous to Palaeogene neritic carbonate succession, as well as from the Flysch itself, as marl clasts are observed in some megabeds. It can be assumed
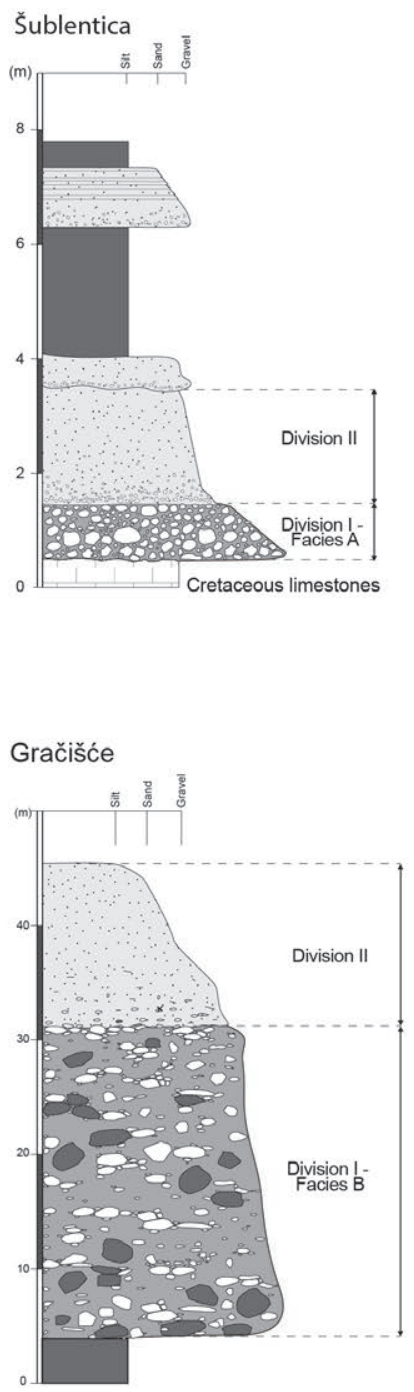
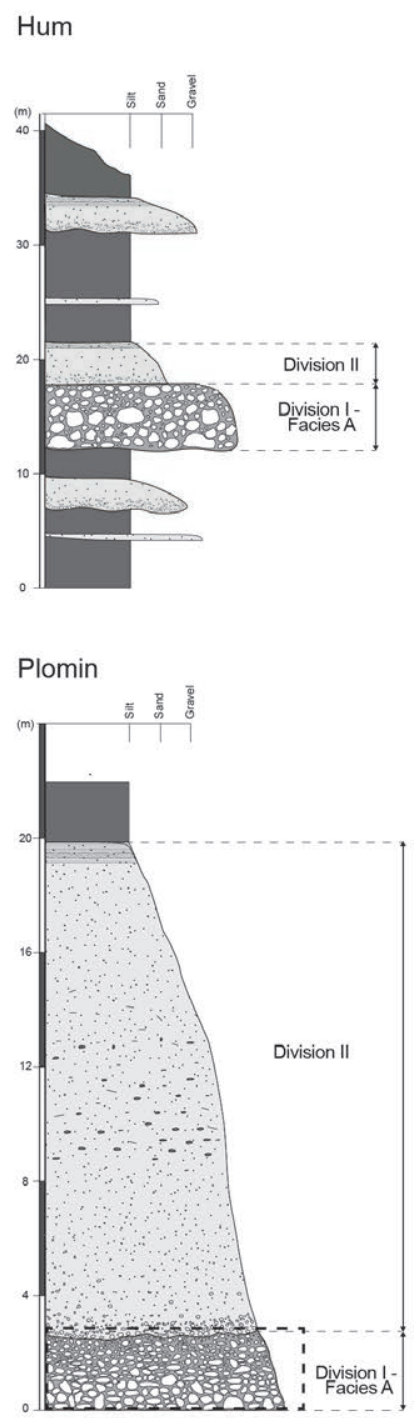
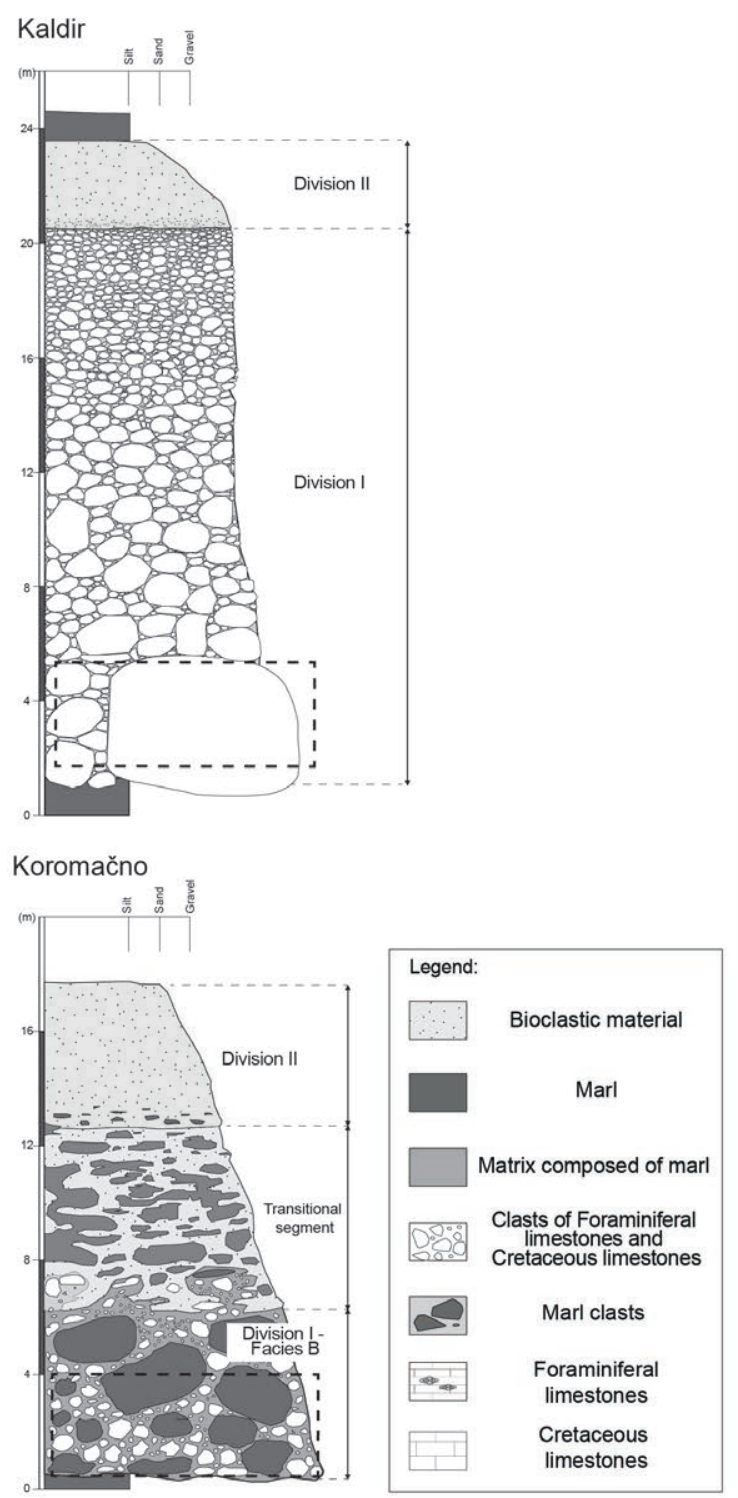

Figure 18. A comparative figure showing simplified logs of all the megabeds. The major differences are in the structure of the Division I breccia - deposited by either a mud- or clast- dominated debris flow, or a submarine avalanche. Also, note that each Division I breccia is characterized by a specific composition (Fig. 3). 
that the synsedimentary faults that generated submarine failures formed along the carbonate ramps within the fast evolving distal foredeep (cf. SINCLAIR, 1997; BARNOLAS \& TEIXELL, 1994, Fig. 16). The faulting also led to the exposure of the older carbonates along the fault scarps thus exposing them to erosion along the steep slopes. The slope collapses, eventually occurring along the fault scarps, generated the mass flows which transported the large quantities of carbonate material (both bioclastic detritus from synchronous carbonate ramps and clasts from older neritic limestones) from the scalloped scarps (Figs. 2 and 16), and also reworked the autochthonous basinal marls. The earthquakes related to the tectonic evolution of the approaching Dinaric orogen could have been the main triggering mechanism for the submarine collapses. The tectonic triggering mechanisms related to deposition of the megabeds in the perialpine foreland basins have already been documented and described (MUTTI et al., 1984; KLEVERLAAN, 1987; PINI et al 2012; OGATA et al., 2020).

TARLAO et al. (1995) supposed that the ongoing orogenic deformation led to subaerial exposure of the basement carbonate succession. In this way the carbonate margins could have been weakened by subaerial processes and thus have been more prone to slope failures. If that was the case, the whole carbonate succession would have been karstified, both Cretaceous and Foraminiferal limestones. However, no karstified Foraminiferal limestones were seen within the megabed clasts. This brings us to the conclusion that the only period of emergence and subaerial exposure was prior to deposition of the Foraminiferal limestones, the Upper Cretaceous to Palaeogene forebulge stage as described by OTONIČAR (2007) and KORBAR (2009).

Furthermore, the studied megabeds are located randomly in the stratigraphy, without any precursive or successive facies associations, suggesting a seismically triggered slope collapse. In other cases, they would occur within major changes in sedimentation patterns, such as at the base of a coarse-grained fan as in the Middle Dalmatian basin, where deposition of the megabeds is attributed to periods of accelerated sea-level rise (MARJANAC, 1996). In the Middle Dalmatian Basin, megabeds have been related to accelerated sea-level rise sometime after a lowstand, since they are interbedded with fan deltas (MARJANAC, 1996) which is not the case with the Istrian megabeds. Although the connection between global sea level change and deposition of the Istrian megabeds is not yet established, a possible sea level drop during the Middle Eocene could have had an impact on resedimented carbonates in Istria.

Time correlation between the Istrian megabeds and global sea level data (e.g. HAQ et al., 1987) is not yet possible, since the available data about the megabeds age is too imprecise. Moreover, the megabeds are present in various stratigraphic parts of the Istrian Flysch. The Kaldir, Šublentica, and Hum occurrences (Fig. 2) are positioned in the lower part of the Istrian Flysch succession while those at Gračišće, Plomin, and Koromačno (Fig. 2) are in the middle, and thus were probably deposited during various sea level stands. Thus, the collapse events are more probably related to tectonic activity than to a specific sea level stand (Fig. 16). The diverse influence of tectonics on the sediment deposition in foreland basins has been documented at various locations in the literature (KLEVERLAAN, 1987; BARNOLAS \& TEIXELL, 1994; PAYROSE et al., 1999; TOMASSO \& SINCLAIR, 2014; GOBO et al., 2021).

Although we concluded that depositions of the megabeds are mainly induced by tectonics, it is not yet clear if collapses that generated mass flows are rather related to normal faulting within the distal part of the foredeep basin (Fig. 16A) or also to thrust faulting in the proximal part, i.e., in front of the orogenic wedge (Fig. 16B). During the evolution of the Istrian foreland basin the normal faults could have dissected the distal foredeep and even generated intrabasinal topographic highs (horsts) and in that way exposed the older rocks along the fault scarps (Fig. 16A). Also, the backstepping and retreat of the carbonate platforms, located in the distal parts of the foreland basin, could induce the collapse of platform margins as described in the Jaca basin, and Pyrennian foreland (BARNOLAS \& TEIXELL, 1994). The alternative option is that some megabeds, at least the most proximal location of Hum, are related to aborted thrust faults in front of the orogenic wedge (Fig. 16B).

\section{CONCLUSIONS}

Based on the data presented here, several concluding remarks can be made about the Istrian megabeds.

Megabeds in the Middle Eocene Istrian Flysch are considered to represent single event bipartite mass transport deposits with a complex structure that implies a complex flow mechanism and flow transformations. The lower parts of the megabed (Division I) are composed of debris flow deposits or even rock avalanche deposits (Kaldir). The upper part (Division II) is composed of turbidity current deposits.

The megabeds are composed of: a) lithoclasts derived from older neritic limestones underlying the Flysch; b) bioclastic sediments derived from synchronous carbonate ramps, and c) reworked basinal sediments (predominantly hemipelagic marls).

In addition to different structural features, each megabed has a distinct clast composition (Lower and Upper Cretaceous limestones as well as the Eocene Foraminiferal limestones) indicating that each bed is a sedimentary record of a specific local slope failure that scalloped a different part of the Cretaceous to Palaeogene carbonate succession underlying the Flysch. Thus, each described megabed probably represents a separate local collapse within the Dinaric foredeep.

The synsedimentary faults dissected the floor of the evolving distal Dinaric foredeep and exposed the basement rocks along the submarine fault scarps. Seismic shocks related to the approaching orogen are proposed as the main triggering mechanism for the collapses along the fault scarps and/or oversteepened slopes.

\section{ACKNOWLEDGEMENT}

The research is partly based on the results of the mapping project for the Basic Geological Map of the Republic of Croatia in scale 1:50.000 and scientific research within project GEOSEKVA (Grant no. IP-2016-06-1854) funded by the Croatian Science Foundation. Special thanks to Lara WACHA for suggestions during the writing of the manuscript, and Ladislav FUČEK for helping with the determinations of the Cretaceous limestones. Also, the authors would like to thank Holcim Croatia for the hospitality at their quarry at Koromačno. Kei OGATA, Marco PATACCI and two Anonymous Reviewers significantly contributed to the improvement of an earlier version of this manuscript.

\section{REFERENCES}

ABBATE, E., BORTOLOTTI, V. \& PASSERINI, P. (1970): Olistostromes and olistoliths.-In: SESTINI, G. (ed.): Development of the northern Apennines geosyncline: Sedimentary Geolology, 4, 521-557.

AMY, L., KNELLER, B. \& MCCAFFREY, W. (2007): Facies architecture of the Grès de Peïra Cava, SE France: Landward stacking patterns in ponded turbiditic basins.Journal of The Geological Society, 164/1, 143-162. doi: 10.1144/0016-76492005019 
AUBOUIN, J., BLANCHET, R., CADET, J.-P., CELET, P., CHARVET, J., CHOROWICZ, J., COUSIN, M. \& RAMPNOUX, J-P. (1970): Essai sur la geologie des Dinarides.- Bulletin de la Société Géologique de France, 12/6, 1060-1095.

BABIĆ, LJ. \& ZUPANIČ, J. (1983): Paleogene clastic formations in northern Dalmatia.- In: BABIĆ, LJ. \& JELASKA, V. (eds.): Contributions to Sedimentology of some Carbonate and Clastic Units of the Coastal Dinarides, Excursion Guidebook. International Association of Sedimentologists 4th Regional Meeting, Split, 37-61.

BABIĆ, LJ., \& ZUPANIČ, J. (1996): Coastal Dinaric flysch belt: palaeotransport model for the Pazin Basin, and the role of a foreland uplift.- Natura Croatica, 5, 317-327.

BABIĆ LJ., HERNITZ-KUČENJAK, M., ĆORIĆ, S. \& ZUPANIČ, J. (2007): The Middle Eocene age of the supposed Late Oligocene sediments in the flysch of the Pazin Basin (Istria, Outer Dinarides).- Natura Croatica: periodicum Musei historiae naturalis Croatici, 16/2, 83-103.

BARATTOLO, F., BASSI, D. \& ROMANO, R. (2007): Upper Eocene larger foraminiferal-coralline algal facies from the Klokova Mountain (southern continental Greece).- Facies, 53, 361-375. doi: 10.1007/s10347-007-0108-2

BARNOLAS, A. \& TEIXELL, A. (1994): Platform sedimentation and collapse in a carbonate-dominated margin of a foreland basin (Jaca basin, Eocene, south Pyrenees).- Geology, 22/12, 1107-1110. doi: 10.1130/0091-7613(1994)022<1107:PS ACIA $>2.3 . \mathrm{CO} ; 2$

BASSI, D. (2005): Larger foraminiferal and coralline algal facies in an Upper Eocene storm-influenced, shallow water carbonate platform (Colli Berici, northeastern Italy).- Palaeogeography Palaeoclimatology Palaeoecology, 226/17, 17-35. doi: 10.1016/j.palaeo.2005.05.002

BENIĆ, J. (1991): The age of the Istria Flysch deposits based on calcareous nannofosils.- In: DROBNE, K. \& PAVLOVEC, R. (eds.): Introduction to the Paleogene SW Slovenia and Istria. Field-Trip Guidebook IGCP Project, Early Paleogene Benthos, 2nd meeting Postojna (Slovenia, Istria), p. 25.

BERGANT, S., TIŠLJAR, J. \& ŠPARICA, M. (2003): Eocene Carbonates and Flysch Deposits of the Pazin Basin.- In: VLAHOVIĆ, I. \& TIŠLJAR, J. (eds.): Field Trip Guidebook - 22nd IAS Meeting of Sedimentology - Opatija 2003, 57-63.

BERGANT, S., MATIČEC, D., FUČEK, L., PALENIK, D., KORBAR, T., ŠPARICA, M., KOCH, G., GALOVIĆ, I. \& PRTOLJAN, B. (2020): Basic Geological Map of the Republic of Croatia scale 1:50.000, sheet: Rovinj 2- Department of Geology, Croatian Geological Survey, Zagreb.

BOSENCE, D.W.J. (2005): A genetic classification of carbonate platforms based on their basinal and tectonic settings in the Cenozoic.- Sedimentary Geology, 175/1-4, 49-72. doi: 10.1016/j.sedgeo.2004.12.030

BOUMA, A.H. (1987): Megaturbidite: An acceptable term?- Geo-Marine Letters, 7, 63-67. doi: 10.1007/BF02237985

CROATIAN GEOLOGICAL SURVEY (2009): Geological Map of the Republic of Croatia at the Scale 1:300. 000.- Croatian Geological Gurvey, Department of Geology, Zagreb.

ĆORIĆ, S., BABIĆ, LJ., HERNITZ KUČENJAK, M. \& ZUPANIČ, J. (2008): Conflicting dating of the coastal Dinaric flysch, and implications: Eocene or Miocene? The case of north Dalmatia and Istria.- Geophysical Research Abstracts, p. 10.

ĆOSOVIĆ, V., DROBNE, K. \& MORO, A. (2004): Paleoenvironmental model for Eocene foraminiferal limestones of the Adriatic carbonateplatform (Istrian Peninsula).- Facies, 50, 61-75.

ĆOSOVIĆ, V., MARJANAC, T., DROBNE, K. \& MORO, A. (2008): Outer Dinarides: eastern Adriatic coast. Paleogene and Neogene.- In: McCANN, T. (ed.): The Geology of Central Europe, Volume 2: Mesozoic and Cenozoic. The Geological Society London, London, 1031-1139.

ĆOSOVIĆ, V., MRINJEK, E, NEMEC, W., ŠPANIČEK, J. \& TERZIĆ, K. (2018): Development of transient carbonate ramps in an evolving foreland basin.- Basin Research, 30, 746-765, doi: 10.1111/bre.12274

DROBNE, K. (1977): Alvéolines paléogènes de la Slovénie et de l'Istrie.- Mémoires suisses de Paléontologie, 99, $174 \mathrm{p}$.

DUNHAM, R.J. (1962): Classification of carbonate rocks according to depositional texture.- In: HAM, W.E. (ed.): Classification of Carbonate Rocks. American Association of Petroleum Geologists Memoir, 1, 108-121.

EMBRY, A.F. \& KLOVAN, J.E. (1971): A late Devonian reef tract on northeastern Banks Island, N.W.T.- Bulletin of Canadian Petroleum Geology, 19/4, 730-781.

FALLGATTER, C., KNELLER, B., PAIM, P.S. \& MILANA, J.P. (2016): Transformation, partitioning and flow-deposit interactions during the run-out of megaflows.Sedimentology, 64/2, 359-387. doi: 10.1111/sed.12307

FELIX, M., LESZCZYŃSKI, S., SLACZKA, A., UCHMAN, A., AMY, L. \& PEAKALL, J. (2009): Field expressions of the transformation of debris flows into turbidity currents, with examples from the Polish Carpathians and the French Maritime Alps.- Marine and Petroleum Geology, 26/10, 2011-2020. doi: 10.1016/j.marpetgeo.2009.02.014

FESTA, A., PINI, G. A., OGATA, K. \& DILEK, Y. (2019): Diagnostic features and fieldcriteria in recognition of tectonic, sedimentary and diapiric mélanges in orogenic belts and exhumed subduction-accretion complexes.- Gondwana Research, 74, 7-30. doi: 10.1016/j.gr.2019.01.003
FLÜGEL, E. (2004): Microfacies of Carbonate Rocks: Analysis, Interpretation and Application.- Springer-Verlag, Berlin, 976 p. doi: 10.1017/S0016756806221940

GOBO, K., MRINJEK, E. \& ĆOSOVIĆ, V. (2021): Mass-transport deposits and the onset of wedge-top basin development: An example from the Dinaric Foreland Basin, Croatia.- Journal of Sedimentary Research, 90/11, 1527-1548. doi: 10.2110/ jsr.2019.192

HAGN, H., PAVLOVEC, R. \& PAVŠIĆ, J. (1979): Excursion G, Gračišće near Pićan, Istria-Eocene.- In: Excursions Guidebook, 16. European Micropalaeontological Colloquium, Ljubljana, 185-190.

HALLOCK, P. \& GLENN, E.C. (1986): Larger Foraminifera: A Tool for Paleoenvironmental Analysis of Cenozoic Carbonate Depositional Facies.- Palaios, 1/1, 55-64. doi: $10.2307 / 3514459$

HAMPTON, M.A. (1972): The role of subaqueous debris flow in generating turbidity currents.- Journal of Sedimentary Research, 42/4, 775-793. doi: 10.1306/74D7262B-2B21-11D7-8648000102C1865D

HAUGHTON, P., BARKER, S. \& MCCAFFREY, W. (2003): 'Linked' debrites in sandrich turbidite systems - origin and significance.- Sedimentology, 50/3, 459-482. doi: 10.1046/j.1365-3091.2003.00560.x

HAUGHTON, P., DAVIS, C., MCCAFFREY, W. \& BARKER, S. (2009): Hybrid sediment gravity flow deposits - classification, origin and significance.- Mar. Petroleum Geology, 26/10, 1900-1918. doi: 10.1016/j.marpetgeo.2009.02.012

HAQ, B., HARDENBOL, J.R. \& VAIL, P. (1987): Chronology of Fluctuating Sea Levels Since the Triassic.- Science, 235/4793, 1156-67. doi: 10.1126/science.235.4793.1156

JURAČIĆ, M. (1980): Depth of sedimentation of Marl with crabs estimated from the ratio between planktonic and benthic foraminifera.- Geološki vjesnik, 31, 61-67.

KLEVERLAAN, K. (1987): Gordo Megabed: a possible seismite in a Tortonian submarine fan, Tabernas Basin, Province Almeria, southeast Spain.- Sedimentary Geolology, 51/3-4, 165-180. doi: 10.1016/0037-0738(87)90047-9

KORBAR, T. (2009): Orogenic evolution of the External Dinarides in the NE Adriatic region: a model constrained by tectonostratigraphy of Upper Cretaceous to Paleogene carbonates.- Earth-Science Reviews, 96/4, 296-312. doi: 10.1016/j.earscirev.2009.07.004

KRAŠENINNIKOV, V.A., MULDINI-MAMUŽIĆ, S. \& DŽODŽO-TOMIĆ, R. (1968): Signification des foraminiferes planctoniques pour la division du Paléogene de la Yougoslavie et comparaison avec les autres régions examinées.- Geološki vjesnik, $21,117-145$

LABAUME, P., MUTTI, E. \& SEGURET, M. (1987): Megaturbidites: A depositional model from the eocene of the SW-Pyrenean Foreland basin, Spain.- Geo-Marine Letters, 7/2, 91-101. doi: 10.1007/BF02237988

LOWE, D.R. (1982): Sediment gravity flows: II depositional models with special reference to the deposits of high-density turbidity currents.- Journal od Sedimentary Petrology, 52/1, 279-297. doi: 10.1306/212F7F31-2B24-11D7$8648000102 \mathrm{C} 1865 \mathrm{D}$

MAGAŠ, N. (1973): Osnovna geološka karta SFR Jugoslavije, 1:100000, Tumač za list Cres L33-113, [Basic Geological Map of SFRY 1:100.000, Geology of the Cres sheet - in Croatian, English Abstr.].- Institut za geološka istraživanja, Zagreb, Savezni geološki zavod, Beograd, $42 \mathrm{p}$.

MAGDALENIĆ, Z. (1972): Sedimentologija flǐ̌kih naslaga Srednje Istre [Sedimentology of Central Istria flysch deposits - in Croatian, English abstr.].- Prirodoslovna istraživnja, knjiga, 39, 71-100.

MARINČIĆ, S. (1981): Eocenski fliš Jadranskog pojasa [Eocene flysch of Adriatic area - in Croatian, English abstr.].- Geološki vjesnik, 34, 27-38.

MARINČIĆ, S., ŠPARICA, M., TUNIS, G. \& UCHMAN, A. (1996): The eocene flysch deposits of the Istrian peninsula in Croatia and Slovenia. Regional, stratigraphic, sedimentological and ichnological analysis.- Annales, 9, 139-156.

MARJANAC, T. (1990): Reflected sediment gravity flows and their deposits in flysch of Middle Dalmatia, Yugoslavia.- Sedimentology, 37/5, 921-929.

MARJANAC, T. (1991): Importance of megabeds for reconstruction of Paleogene flysch basin in Split hinterland (Middle Dalmatia).- Geološki vjesnik, 44, 201-213.

MARJANAC, T. (1993): Evolution of Eocene-Miocene flysch basin of Central Dalmatia, Croatia.- Unpubl. PhD Thesis, University of Zagreb, 348 p.

MARJANAC, T. (1996): Deposition of megabeds (megaturbidites) and sea-level change in a proximal part of Eocene-Miocene flysch of central Dalmatia (Croatia).- Geology, 24/6, 543-546. doi: 10.1130/0091-7613(1996)024<0543:DOMMAS $>2.3$. $\mathrm{CO} ; 2$

MARJANAC, T. \& ĆOSOVIĆ, V. (2000): Tertiary depositional history of Eastern Adriatic realm.- Vijesti Hrvatskog geološkog društva, 37/2, 93-103.

MATIČEC, D., VLAHOVIĆ, I., VELIĆ, I. \& TIŠLJAR, J. (1996): Eocene limestones overlying Lower Cretaceous deposits of western Istria (Croatia): Did some parts of present Istria form land during the Cretaceous?- Geologia Croatica, 49/1, $117-127$.

MIKES, T. \& BÁLDI-BEKE, M. \& KAZMER, M. \& DUNKL, I. \& EYNATTEN, H. (2008): Calcareous nannofossil age constraints on Miocene flysch sedimentation in the Outer Dinarides (Slovenia, Croatia, Bosnia-Herzegovina and Montenegro).- 
Geological Society, London, Special Publications, 298, 335-363. doi: 10.1144/ SP298.16

MULDER, T. \& ALEXANDER, J. (2001): The physical character of subaqueous sedimentary density flow and their deposits.- Sedimentology, 48/2, 269-299. doi: 10.1046/j.1365-3091.2001.00360.x

MUTTI, E., RICCI LUCCHI, F., SEGURET, M. \& ZANZUCCHI, G. (1984): Seismoturbidites: A new group of resedimented deposits.- Marine Geology, 55/1-2, 103-116. doi: 10.1016/0025-3227(84)90135-X

OGATA, K., POGAČNIK, Ž., PINI, G.A., TUNIS, G., FESTA, A., CAMERLENGHI, A. \& REBESCO, M. (2014): The carbonate mass transport deposits of the Paleogene Friuli Basin (Italy/Slovenia): Internal anatomy and inferred genetic processes.- Marine Geology, 356, 88-110. doi: 10.1016/j.margeo.2014.06.014

OGATA, K., POGAČNIK, Ž.,TUNIS, G., PINI, G.A., FESTA, A. \& SENGER, K. (2019): A Geophysical-Geochemical Approach to the Study of the Paleogene Julian-Slovenian Basin "Megabeds" (Southern Alps-Northwestern Dinarides, Italy/ Slovenia).- Geosciences, 9/4, 1-17. doi: 155. 10.3390/geosciences9040155

OGATA, K., FESTA, A., PINI, G.A. \& ALONSO, J.L. (2020): Submarine Landslide Deposits in Orogenic Belts: Olistostromes and Sedimentary Mélanges in Submarine Landslides.- In OGATA, K., FESTA, A. \& PINI, G.A. (eds): Submarine Landslides: Subaqueous Mass Transport Deposits from Outcrops to Seismic Profiles, Geophysical Monograph 246, American Geophysical Union. John Wiley \& Sons, 3-26. doi: 10.1002/9781119500513.ch1

OTONIČAR, B. (2007): Upper Cretaceous to Paleogene forbulge unconformity associated with foreland basin evolution (Kras, Matarsko podolje and Istria; SW Slovenia and NW Croatia).-Acta Carsologica, 36/1, 101-120. doi: 10.3986/ac.v36i1.213

PAYROS, A., PUJALTE, V. \& ORUE-ETXEBARRIA, X. (1999): The South Pyrenean Eocene carbonate megabreccias revisited: new interpretation based on evidence from Pamplona Basin.- Sedimentary Geology, 125/3-4, 165-194. doi: 10.1016/ S0037-0738(99)00004-4

PICCOLI, G. \& PROTO DECIMA, F. (1969): Ricerche biostratigrafiche sui depositi flyschoidi della regione adriatica settentrionale e orientale.- Memorie degli Instituti di Geologia Mineralogia dell'Universitŕ di Padova, 27, 1-23.

PINI, G.A., OGATA, K., CAMERLENGHI, A., FESTA, A., LUCENTE, C.C. \& CODEGONE, G. (2012): Sedimentary melanges and fossil mass-transport complexes: A key for better understanding submarine mass movements?- In: YAMADA, Y., KAWAMURA, K., IKEHARA, K., OGAWA, Y., URGELES, R., MOSHER, D., CHAYTOR, J. \& STRASSER, M. (eds.): Submarine mass movements and their consequences, Advances in Natural and Technological Hazards Research, 31, Dordrecht, Springer Science+BusinessMedia B.V., 585-594. doi: 10.1007/978-94007-2162-3 52

POLŠAK, A. \& ŠIKIĆ, D. (1973): Osnovna geološka karta SFR Jugoslavije, 1:100000, Tumač za list Rovinj L30-100, [Basic Geological Map of SFRY 1:100.000, Geology of the Rovinj sheet - in Croatian, English Abstr.].- Institut za geološka istraživanja, Zagreb, Savezni geološki zavod, Beograd, 51 p.

RASSER, M.W., \& PILLER W.E. (2004): Crustose algal frameworks from the Eocene Alpine Foreland.-Palaeogeography, Palaeoclimatology, Palaeoecology, 206/1-2, 21-39. doi: 10.1016/j.palaeo.2003.12.018

SCHMID, S.M., BERNOULLI, D., FÜGENSCHUH, B., MATENCO, L., SCHEFER, S., SCHUSTER, R., TISCHLER, M. \& USTASZEWSKI, K. (2008): The AlpineCarpathian-Dinaridic orogenic system: correlation and evolution of tectonic units.Swiss Journal of Geosciences, 101, 139-183. doi: 10.1007/s00015-008-1247-3

SHANMUGAM, G. (2006): Deep-water processes and facies models: Implications for sandstone petroleum reservoirs: Amsterdam, Elsevier-- Handbook of petroleum exploration and production, 5, 476 $\mathrm{p}$.

SINCLAIR, H.D. (1997): Tectonostratigraphic model for underfilled peripheral foreland basins.-GSABulletin, 109/8,324-346. doi: 10.1130/0016-7606(1997)109<0324:TM$\mathrm{FUPF}>2.3 . \mathrm{CO} ; 2$
ŠIKIĆ, D. \& POLŠAK, A. (1973): Osnovna geološka karta SFR Jugoslavije, 1:100000, Tumač za list Labin L33-101 [Basic Geological Map of SFRY 1:100.000, Geology of the Labin sheet - in Croatian, English Abstr.].- Institut za geološka istraživanja, Zagreb, Savezni geološki zavod, Beograd, 55 p.

ŠIKIĆ, D. \& PLENIČAR, M. (1975): Osnovna geološka karta SFR Jugoslavije, 1:100000, Tumač za list Ilirska Bistrica L33-89 [Basic Geological Map of SFRY 1:100.000, Geology of the Ilirska Bistrica sheet - in Croatian, English Abstr.].Institut za geološka istraživanja, Zagreb, Geološki zavod. Ljubljana, Savezni geološki zavod, Beograd, 51 p.

ŠPELIĆ, M., DEL BEN, A. \& PETRINJAK, K. (2021): Structural setting and geodynamics of the Kvarner area (Northern Adriatic).- Marine and Petroleum Geology, 125, 104857. doi: 10.1016/j.marpetgeo.2020.104857

TALLING, P. (2013): Hybrid submarine flows comprising turbidity current and cohesive debris flow: Deposits, theoretical and experimental analyses, and generalized models.- Geosphere, 9, 460-488. doi: 10.1130/GES00793.1

TARLAO, A., TUNIS, G. \& VENTURINI, S. (1995): Lutetian Transgression in Central Istria: the Rogovići-Mećari section case.- In: VLAHOVIĆ, I., VELIĆ, I. \& ŠPARICA, M. (eds): Proceedings 2, First Croatian Geological Congress. Institute of Geology, Zagreb, 613-618.

TARLAO, A., TUNIS, G. \& VENTURINI, S. (2005): Dropstones, pseudoplanktonic forms and deep-waterdecapod crustaceans within a Lutetian condensed succession of central Istria (Croatia): relation to palaeoenvironmental evolution and palaeogeography.- Palaeogeography, Palaeoclimatology, Palaeoecology, 218/3-4, 325-345. doi: 10.1016/j.palaeo.2004.12.023

TOMASSO, M. \& SINCLAIR, H. (2004): Deep-water sedimentation on an evolving fault-block: The Braux and St Benoit outcrops of the Grès d'Annot.- Geological Society, London, Special Publications, 221, 267-283. doi: 10.1144/GSL. SP.2004.221.01.14

TUNIS, G. \& VENTURINI, S. (1992): Evolution of the Southern Margin of the Julian Basin with Emphasis on the Mega Beds and Turbidites Sequence of the Southern Julian Prealps (NE Italy).- Geologia Croatica, 45, 127-150.

VLAHOVIĆ, I., TIŠLJAR, J., VELIĆ, I. \& MATIČEC, D. (2005): Evolution of the Adriatic Carbonate Platform: Palaeogeography, main events and depositional dynamics.-Palaeogeography, Palaeoclimatology, Palaeoecology, 220/3-4, 333-360. doi: 10.1016/j.palaeo.2005.01.011

VLAHOVIĆ, I. \& VELIĆ, I. (2009): Liburnijske naslage, foraminiferski vapnenci i prijelazne naslage (?gornji paleocen, donji i srednji eocen-?Pc, E1,2) [Liburnian deposits, Foraminiferal limestones and Transitional Beds (?Upper Paleocene, Lower and Middle Eocene -?Pc, E1,2 - in Croatian].- In: VELIĆ, I. \& VLAHOVIĆ, I. (eds.): Tumač Geološke karte Republike Hrvatske 1:300000 [Explanatory Notes of Basic Geological Map of Croatia 1:300.000 - in Croatian]. Hrvatski geološki institut, Zagreb, 76-77.

VELIĆ, I., TIŠLJAR, J., VLAHOVIĆ, I., MATIČEC, D. \& BERGANT, S. (2003): Evolution of the Istrian part of the Adriatic Carbonate Platform from the Middle Jurassic to the Santonian and Formation of the Flysch Basin during the Eocene: Main Events and Regional Comparison.- In: VLAHOVIĆ, I. \& TIŠLJAR, J. (eds.): Field Trip Guidebook - 22nd IAS Meeting of Sedimentology - Opatija. Croatian Geological Survey, Zagreb, 57-63.

VELIĆ, I. (2007): Stratigraphy and Palaeobiogeography of Mesozoic Benthic Foraminifera of the Karst Dinarides (SE Europe).- Geologia Croatica, 60/1, 1-113.

ŽIVKOVIĆ, S. \& BABIĆ, LJ. (2003): Paleoceanographic implications of smaller benthic and planktonic foraminifera from the Eocene Pazin Basin (Coastal Dinarides, Croatia).- Facies, 49, 49-60. doi: 10.1007/s10347-003-0024-z

ŽIVKOVIĆ, S. \& GLUMAC, B. (2007): Paleoenvironmental reconstruction of the Middle Eocene Trieste-Pazin basin (Croatia) from benthic foraminiferal assemblages.- Micropaleontology, 53/4, 285-310. doi: 10.2113/gsmicropal.53.4.285 

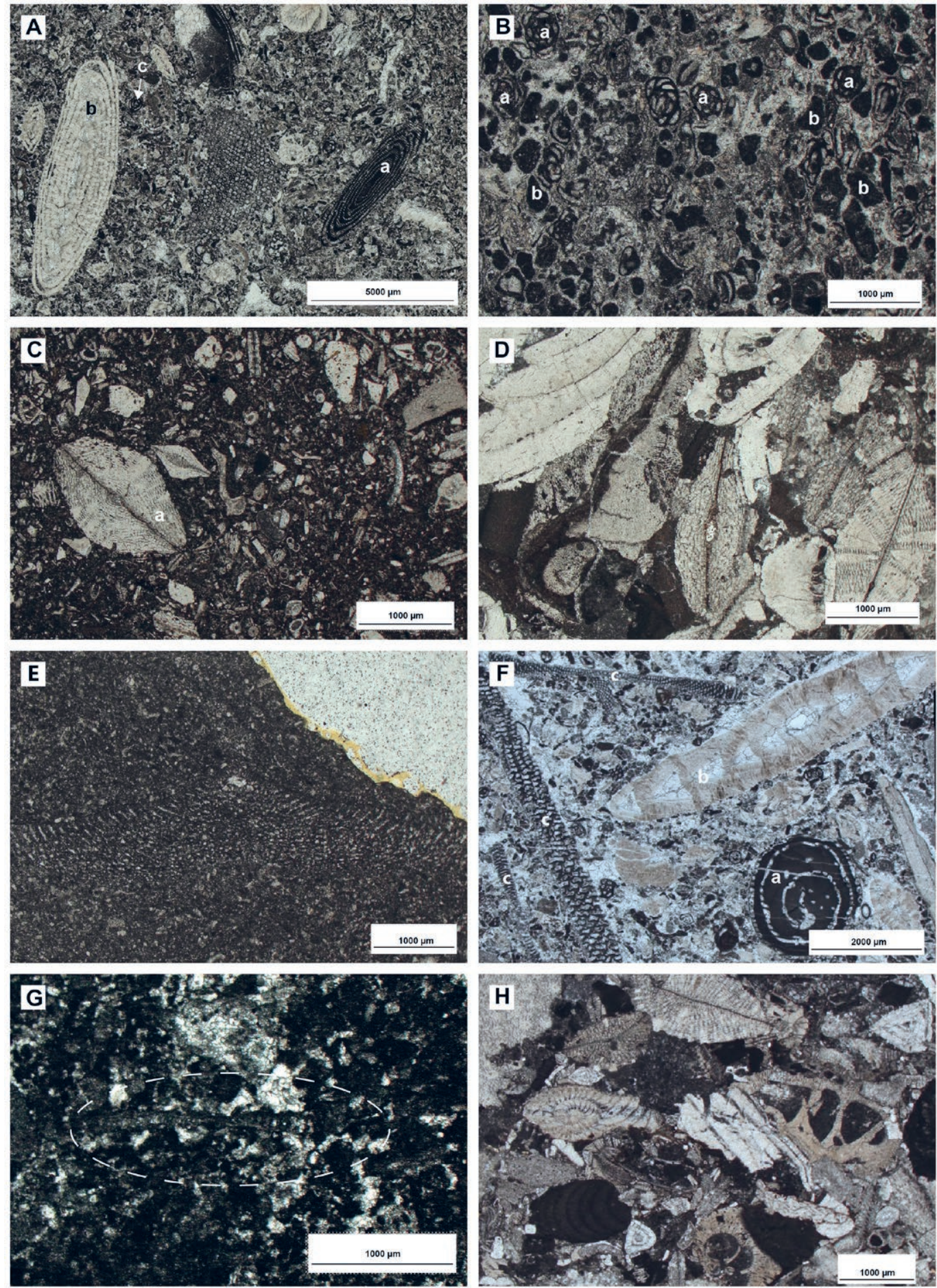

Plate 1. Photomicrographs of the microfacies of the most common clasts from Division I breccia (A, B, C, E, F, and $G$ ) and microfacies of bioclastic material form Division II (D and $\mathrm{H}$ ) of the Šublentica and Hum sections.

A - Nummulitid-alveolinid packstone-grainstone showing the association of alveolinids (a), nummulitids (b) and miliolid (c). Sample Šub-7. Middle Eocene. Šublentica section;

B - Peloid-miliolid packstone-grainstone showing miliolids (a) and peloids (b). Sample Šub-43, middle Cretaceous (Albian-Cenomanian). Šublentica section

C - Orthophragminid wackestone showing ortophragminid test (a) with other bioclastic detritus. Sample Šub-43. Middle Eocene. Šublentica section;

D - Densely packed, well-sorted foraminiferal calcirudite showing large benthic foraminifera tests (mostly orthophragminids and nummulites), red algae (rodoliths), mudstone lithoclasts, and biodetritus (fragments of large benthic foraminifera, encrusting foraminifera, and echinoderms). Sample Šub-II 3. Middle Eocene. Šublentica section;

E - Foraminiferal wackestone showing Palorbitolina lenticularis (BLUMENBACH, 1805). Sample Hum-123. Lower Cretaceous (lower Aptian). Hum section;

F - Nummulitid-alveolinid grainstone showing an association of alveolinids (a), nummulitids, (b), Asillina sp., and Orbitolites sp. (c). Sample Hum 85. Middle Eocene. Hum section;

G - Foraminiferal wackestone showing the recrystallized transversal section of Cenomanian foraminifera Broeckina (Pastrikella) balcanica (CHERCHI, RADOIČIĆ \& SCHROEDER, 1976). Sample Hum-286. Upper Cretaceous. Hum section;

H - Densely packed, well-sorted foraminiferal calcirudite showing fragmented large benthic foraminifera tests (mostly discocyclines/orthophragminids, nummulites, and unidentified rotaliid foraminifera), red algae, and biodetritus. Sample Hum 3b. Middle Eocene Hum section. 

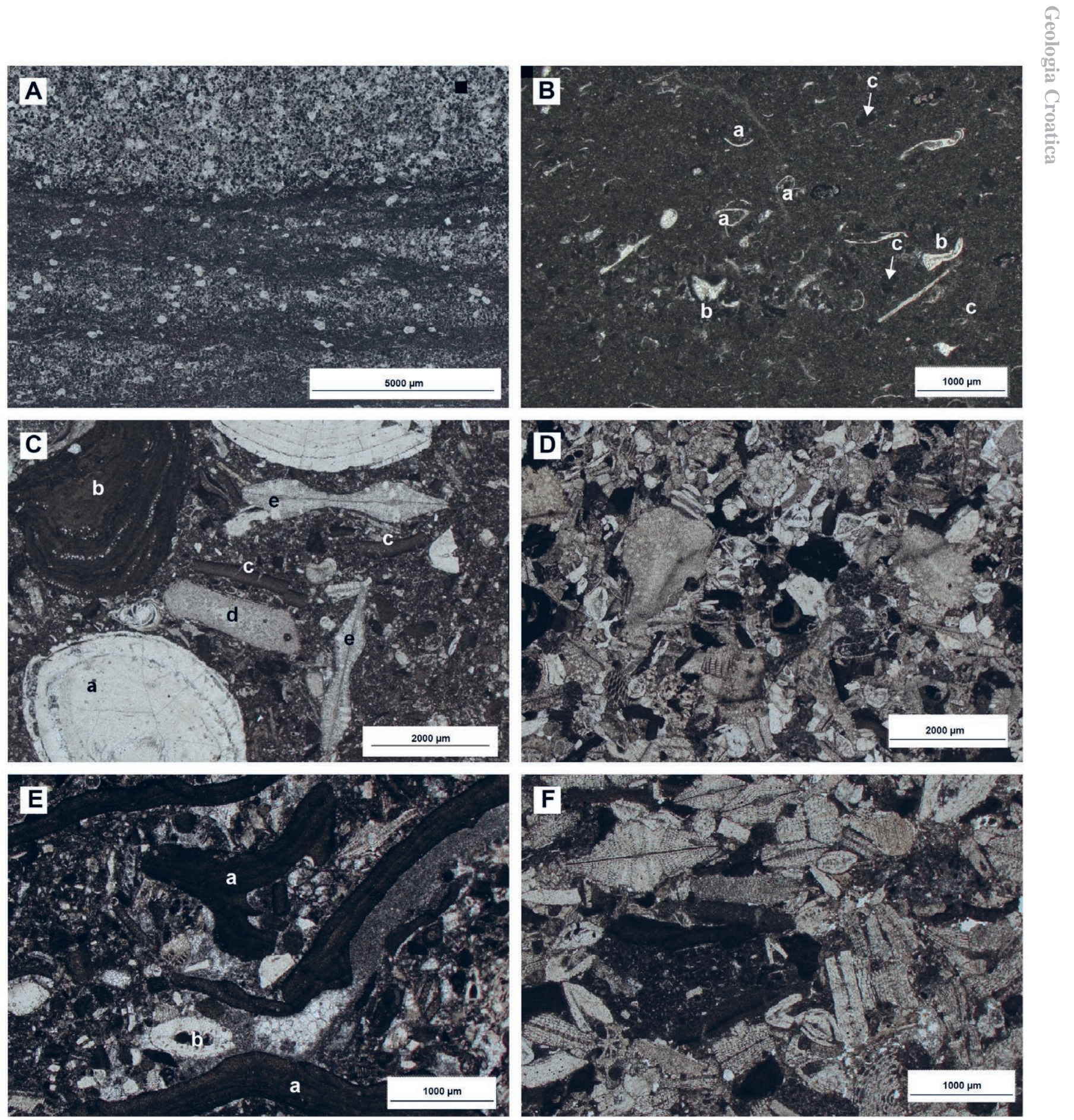

Plate 2. Photomicrographs of the microfacies of the most common clasts from Division I breccia (A, B, C, E, F, and G) and the microfacies of bioclastic material form Division II (D and $\mathrm{H}$ ) of Kaldir and Gračišce sections.

A - Laminated peloidal wackestone-packstone with rare ostracods. Sample K-132. Upper Cretaceous (Cenomanian). Kaldir section

B - Ostracodal mudstone-wackstone, showing ostracods (a), recrystallized Thaumatoporella sp. (b) and Aeolisacus sp. (c). Sample K-152. Upper Cretaceous. Kaldir section;

C - Foraminiferal wackestone-floatstone showing nummulitids (a), red algae - rodoliths (b), red algal crusts (c), echinoderm fragment (d) and orthophragminides (e). Sample K-num. Middle Eocene. Kaldir section;

D - Densely packed, well-sorted foraminiferal calcarenite showing large benthic foraminifera tests (mostly orthophragminids and nummulites), red algae (corallinacea) and biodetritus - fragments of foraminifera, echinoderms, bryozoans and bivalves. Sample Kaldir 1A. Middle Eocene. Kaldir section;

E - Algal wackestone showing red algae framework (a), nummulitids (b), and unidentified bioclastic detritus. Sample Gr-199. Middle Eocene. Gračišće section;

F - Densely packed, well-sorted foraminiferal calcarenite showing large benthic foraminifera tests (mostly orthophragminids and nummulites), red algae crusts, and other biolastic detritus (fragments of large benthic foraminifera, encrusting foraminifera and echinoderms) and mudstone-wackeston lithoclasts. Sample Gračišće-1. Middle Eocene. Gračišće section. 

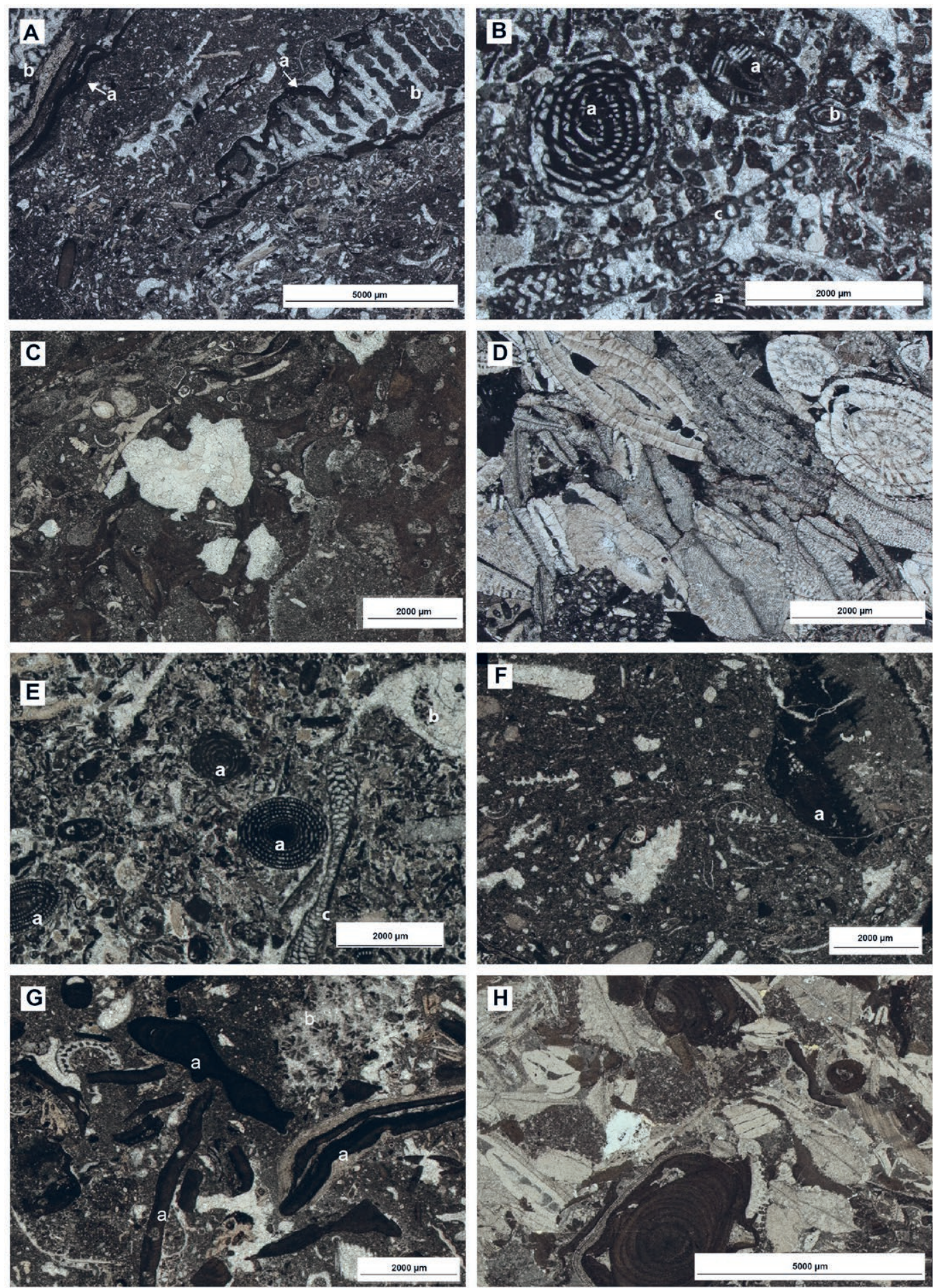

Plate 3. Photomicrographs of the microfacies of the most common clasts from Division I breccia (A, C, D, and E) and microfacies of bioclastic material form Division II (B and F) of Plomin and Koromačno sections.

A - Algal wackestone showing red algae (a) encrusting coral fragments (b) and other unidentified bioclasts. Sample PI-II 123. Middle Eocene. Plomin section;

B - Alveolinid packstone-grainstone showing association of alveolinids (a), miliolids (b), and Orbitolites sp. fragment (c). Sample PI II-124. Middle Eocene. Plomin section;

C - Foraminiferal-algal bindstone showing red algae encrusting mudstone lithoclasts and unidentified bioclast. Sample PI-II 87. Middle Eocene. Plomin section;

D - Densely packed, well-sorted foraminiferal calcirudite showing large benthic foraminifera test (mostly orthophragminids and nummulites), biodetritus of red algae, and a skeletal wackestone lithoclast. Sample PI-3. Middle Eocene. Plomin section;

E - Alveolinid grainstone showing association of alveolinids (a), nummulitids (Asillina sp.), b) and Orbitolites sp (c). Sample KOR II 112. Middle Eocene. Koromačno section;

F - Bioclastic-Algal wackestone with red algae framework (a) and bioclastic detritus. Sample KOR II 162. Middle Eocene. Koromačno section;

G - Algal wackestone showing red algae framework (a), corals (b), and bioclastic detritus. Sample KOR II 179. Middle Eocene. Koromačno section;

H - Densely packed, well sorted foraminiferal calcirudite showing large benthic foraminifera tests (mostly discocyclines/orthophragminids and nummulites), red algae (corallinacea), and biodetritus (fragments of large benthic foraminifera, encrusting foraminifera, and echinoderms). Sample Kor II KA1. Middle Eocene. Koromačno section. 